\title{
Article \\ Mussels Repair Shell Damage despite Limitations Imposed by Ocean Acidification
}

\author{
Matthew N. George ${ }^{1,2, *(\mathbb{D}}$, Michael J. O'Donnell ${ }^{1,2,+}{ }^{\prime}$, Michael Concodello ${ }^{3}$ and Emily Carrington ${ }^{1,2}(\mathbb{D}$ \\ 1 Friday Harbor Laboratories, University of Washington, Friday Harbor, WA 98250, USA; \\ mooseo@berkeley.edu (M.J.O.); ecarring@uw.edu (E.C.) \\ 2 Department of Biology, University of Washington, Seattle, WA 98195, USA \\ 3 Department of Biology, University of Rhode Island, Kingston, RI 02881, USA; mconcodello@gmail.com \\ * Correspondence: mngeorge@uw.edu \\ † Current Address: Department of Bioengineering, University of California, Berkeley, CA 94720, USA.
}

Citation: George, M.N.; O'Donnell, M.J.; Concodello, M.; Carrington, E. Mussels Repair Shell Damage despite Limitations Imposed by Ocean Acidification. J. Mar. Sci. Eng. 2022, 10, 359. https://doi.org/10.3390/ jmse10030359

Academic Editors: Hildegard Westphal, Justin Ries and Steve Doo

Received: 7 January 2022

Accepted: 26 February 2022

Published: 3 March 2022

Publisher's Note: MDPI stays neutral with regard to jurisdictional claims in published maps and institutional affiliations.

Copyright: (C) 2022 by the authors. Licensee MDPI, Basel, Switzerland. This article is an open access article distributed under the terms and conditions of the Creative Commons Attribution (CC BY) license (https:// creativecommons.org/licenses/by/ $4.0 /)$.

\begin{abstract}
Bivalves frequently withstand shell damage that must be quickly repaired to ensure survival. While the processes that underlie larval shell development have been extensively studied within the context of ocean acidification (OA), it remains unclear whether shell repair is impacted by elevated $p \mathrm{CO}_{2}$. To better understand the stereotypical shell repair process, we monitored mussels (Mytilus edulis) with sublethal shell damage that breached the mantle cavity within both field and laboratory conditions to characterize the deposition rate, composition, and integrity of repaired shell. Results were then compared with a laboratory experiment wherein mussels (Mytilus trossulus) repaired shell damage in one of seven $p \mathrm{CO}_{2}$ treatments (400-2500 $\left.\mu \mathrm{atm}\right)$. Shell repair proceeded through distinct stages; an organic membrane first covered the damaged area (days 1-15), followed by the deposition of calcite crystals (days 22-43) and aragonite tablets (days 51-69). OA did not impact the ability of mussels to close drill holes, nor the microstructure, composition, or integrity of end-point repaired shell after 10 weeks, as measured by $\mu \mathrm{CT}$ and SEM imaging, energy-dispersive X-ray (EDX) analysis, and mechanical testing. However, significant interactions between $p \mathrm{CO}_{2}$, the length of exposure to treatment conditions, the strength and inorganic content of shell, and the physiological condition of mussels within OA treatments were observed. These results suggest that while OA does not prevent adult mussels from repairing or mineralizing shell, both OA and shell damage may elicit stress responses that impose energetic constraints on mussel physiology.
\end{abstract}

Keywords: biomineralization; calcification; Mytilus edulis; Mytilus trossulus; predator-prey interactions

\section{Introduction}

Mytilid mussels are bivalve mollusks that perform ecologically important roles within marine ecosystems [1,2] and support an intercontinental fishery that accounts for $6.9 \%$ (1.2 million tonnes) of the USD 250 billion global aquaculture industry [3]. Mussels survive harsh conditions along coastal shores using bivalve shells that protect them from waves, predators, and desiccation [4]. Nearshore ecosystems are subject to substantial environmental variability, including fluctuations in seawater $\mathrm{pH}$ [5]. As a consequence of abiotic and biotic nearshore processes, mussels routinely endure exposure to acidified conditions (with respect to open ocean conditions), resulting in $\mathrm{pH}$ reductions of up to 1 unit for minutes, hours, or even days at a time [6-8]. Ocean acidification (OA), or the incremental decline in oceanic $\mathrm{pH}$ globally that results from the uptake of anthropogenic atmospheric $p \mathrm{CO}_{2}$ by the ocean $[9,10]$, is expected to intensify these processes, resulting in significant consequences for marine shelled organisms [11]. Given their ecological and economic importance, the ability of bivalves to build, maintain, and repair damaged shell under different $p \mathrm{CO}_{2}$ conditions will ultimately determine the impact that $\mathrm{OA}$ has on entire ecological communities and aquaculture production $[12,13]$. 
The distribution of mussels within the intertidal zone is limited by wave forces [14] and predation $[15,16]$. Sea stars, crustaceans, birds, and snails (i.e., muricid gastropods) prey upon mussels by prying, peeling, cracking, and/or drilling shell to access the soft tissue within [17-21]. However, predation attempts on shelled mollusks are frequently unsuccessful, resulting in sublethal shell damage that must be quickly repaired to ensure survival [22,23]. Additionally, endolithic attack by bacteria or fungi [24] can also result in the formation of holes that expose the mantle cavity. Even a temporary breach in shell integrity can be a serious liability, as metabolites that escape the shell cavity quickly attract potential predators [25-27]. Shell breaches can also increase desiccation risk during low tide, stimulate an immune response [28], and hinder acid-base regulation [29]. To mitigate these risks, mussels and other mollusk species are capable of quickly repairing a shell injury by patching holes [30-32]. Using this strategy, mollusks seal off the mantle cavity within hours or days $[33,34]$, although weeks or months may be required to regain the structural integrity of unrepaired shell [35-37].

Mussel shell is a complex biomaterial that is composed of three distinct layers. The outer shell is composed of a proteinaceous covering (periostracum) [38], the middle layer is composed of slender calcite fibers [39], and the innermost layer is composed of tablet aragonite crystals (nacre, 'mother-of-pearl') [40]. The outer mantle (marginal and pallial zones) produces both calcite and aragonite during shell growth, while the inner mantle (central zone) produces aragonite and is involved in shell thickening and repair [41]. In response to shell damage, the mantle extrudes a mixture of polysaccharides and glycoproteins into the extrapallial fluid, forming an organic membrane that covers the interior of the shell breach through a process that has been well described within mollusks [42,43]. A suite of conserved [44] and species-specific [45] shell matrix proteins (SMPs) then determine which mineral polymorph forms on the membrane by facilitating the nucleation, growth, and termination of calcium carbonate crystals (for a review, see [46]). Organic sheet synthesis has been observed to occur 20 days after shell injury in Mytilus, followed by the deposition of calcite crystals (29 days) and aragonite tablets (36 days) [47].

The effect of OA on shell formation in mussels has been well studied at the growth margin [11,48-50], particularly in the context of larval development [51,52] and in the presence of warming [53-55]. Aragonite saturation-state has been shown to be the most influential variable in juvenile mussel and oyster calcification [56]. While not extensively studied in adults, OA can impose metabolic constraints on the biomineralization process [57], resulting in changes in shell shape and thickness [58]. An environmentally induced metabolic constraint could be particularly relevant for shell repair, given the creation and maintenance of the organic matrix is costly $[59,60]$. OA can also impact shell formation through other direct and indirect mechanisms, including a decrease in carbonate ion $\left(\mathrm{CO}^{2-}{ }_{3}\right)$ availability with declining $\mathrm{pH}[56,61]$ and $\mathrm{pH}$-induced metabolic stress that disrupts the intercellular transport mechanisms that support the production of calcium carbonate [62]. However, uncertainty still exists as to the extent to which the processes that underlie shell repair mimic biomineralization at the shell margin [47] and whether the repair process in adults is subject to the same kinetic constraints as in early shell development [63].

Here we present data collected from a field experiment conducted in the rocky intertidal zone of Rhode Island, USA, on the blue mussel (Mytilus edulis; Linnaeus, 1758) and an OA laboratory experiment conducted in Washington, USA, on the pacific blue mussel (Mytilus trossulus; Gould, 1850). Our field observations and experiments serve to determine the frequency with which mussels sustain shell damage and provide a timeline of the shell repair process. These results were then used to inform laboratory mesocosm experiments wherein mussels repaired sublethal shell damage that breached the mantle cavity away from the shell margin under seven OA treatments $\left(p \mathrm{CO}_{2}\right.$ targets: $\left.400-2500 \mu \mathrm{atm}\right)$ for up to 10 weeks. The impact of environmental $p \mathrm{CO}_{2}$ on the progression of the shell repair process, as well as the composition, microstructure, and strength of repaired shell, was then assessed through mechanical testing, SEM imaging, and $\mu \mathrm{CT}$ analysis. 


\section{Materials and Methods}

Datasets presented here are the compilation of field and laboratory experiments undertaken on the Atlantic and Pacific coasts of the United States, utilizing two species of mytilid mussels, M. edulis and M. trossulus, respectively. Initial field observations of the frequency of shell repair in M. edulis populations were collected over three years (1998-2000) during monthly mussel bed surveys within the intertidal zone near Bass Rock and Black Point in Rhode Island, USA $\left(41^{\circ} 24^{\prime} 17.4^{\prime \prime} \mathrm{N}, 71^{\circ} 27^{\prime} 30.5^{\prime \prime} \mathrm{W} ; 41^{\circ} 23^{\prime} 42.4^{\prime \prime} \mathrm{N}, 71^{\circ} 27^{\prime} 47.9^{\prime \prime} \mathrm{W}\right)$, following previously described sampling methods $[64,65]$. The observation that mussels frequently sustained and repaired shell damage from boring predators (Figure 1) motivated field experiments during the summer of 2003. In field experiments, sublethal shell damage that breached the mantle cavity was induced in M. edulis living within bed populations at Black Point; mussels were then resampled over the course of two months to investigate the repair process (Figures 2 and 3). Results of these field experiments were subsequently used to inform a laboratory experiment investigating the effect of ocean acidification $\left(\mathrm{OA}\right.$; elevated seawater $p \mathrm{CO}_{2}$, decreased $\mathrm{pH}$ ) on the shell repair process in $M$. trossulus, conducted during the summer of 2012 at Friday Harbor Laboratories, located on San Juan Island, Washington, USA $\left(48^{\circ} 32^{\prime} 46.9^{\prime \prime} \mathrm{N}, 123^{\circ} 00^{\prime} 36.5^{\prime \prime} \mathrm{W}\right)$.

$M$. trossulus and M. edulis are closely related sister taxa that naturally occur in sympatric populations along the eastern and western coasts of the United States. Due to their genetic similarity and systematic inclusion, along with the Mediterranean mussel (M. galloprovincialis), within the 'Mytilus edulis complex' [66,67], hybridization between the two species is common $[68,69]$. While members of the complex have similar growth rates and physiology [70], shell characteristics can vary. For example, M. edulis typically produces stronger, thicker shells than $M$. trossulus, with the magnitude of this species difference varying by site [71]. However, the material properties and composition of shell (e.g., Young's modulus, Vickers hardness, calcite/aragonite crystallographic orientation) within M. edulis and M. trossulus are not significantly different [72], suggesting their response to shell damage within this study is comparable.
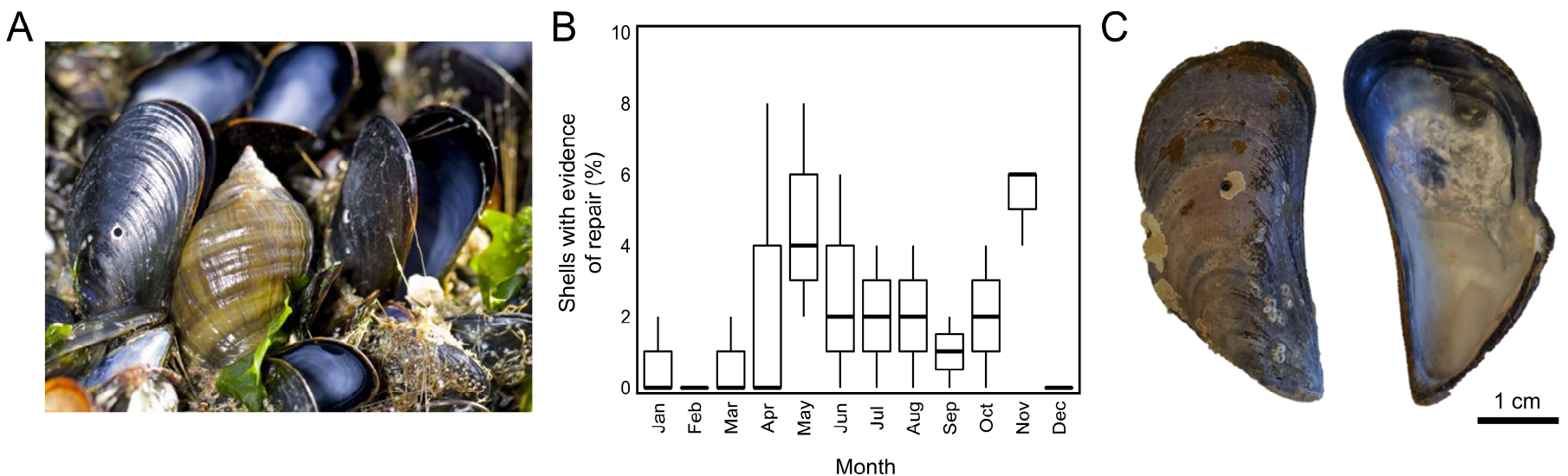

Figure 1. (A) Predation on mussels (Mytilus edulis) by predatory gastropods (Nucella lapillus; image credit: Luke Miller). (B) Mussels (M. edulis, $n=50$ per sample) with evidence of repair of gastropod drill holes over 3 years of monthly field sampling in Rhode Island. (C) Exterior and interior view of a shell (M. edulis) with a repaired drill hole collected during field sampling within Rhode Island. 

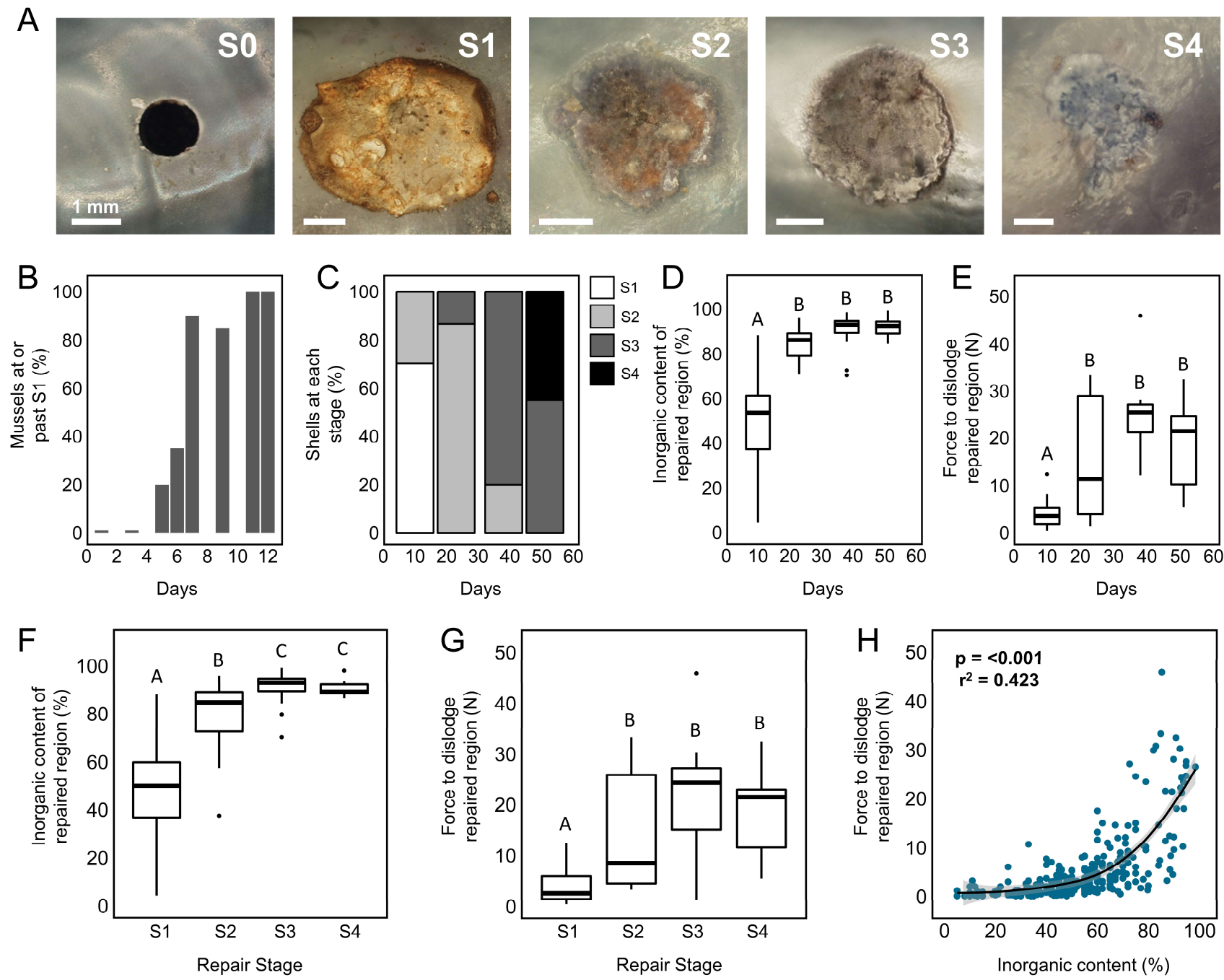

Figure 2. Time series of shell repair process. (A) Photographs of the interior of damaged mussel shells showing the four stereotypical repair stages (S1-S4), as defined in this study. (B) Proportion of mussels (M. trossulus, $n=25$ ) within laboratory experiments that closed drill holes (reached or exceeded S1) over 12 days. Proportion of mussels (M. edulis, $n=15$ per treatment) at each repair stage (C), the inorganic content of excised repaired shell (D), and the force required to dislodge repaired shell (E), from out-planted populations sampled over seven weeks in the intertidal zone. Summary of the inorganic content $(\mathbf{F})$ and force to dislodge $(\mathbf{G})$ repaired shell within each repair stage (pooled data from M. edulis and M. trossulus, $n=282$ ). The relationship between the force required to dislodge repair patches and their inorganic content $(\mathbf{H})$ across field and laboratory experiments using pooled data from both mussel species. Letters within panels indicate the results of tukey HSD post-hoc comparisons; groups that share a letter are not significantly different. 

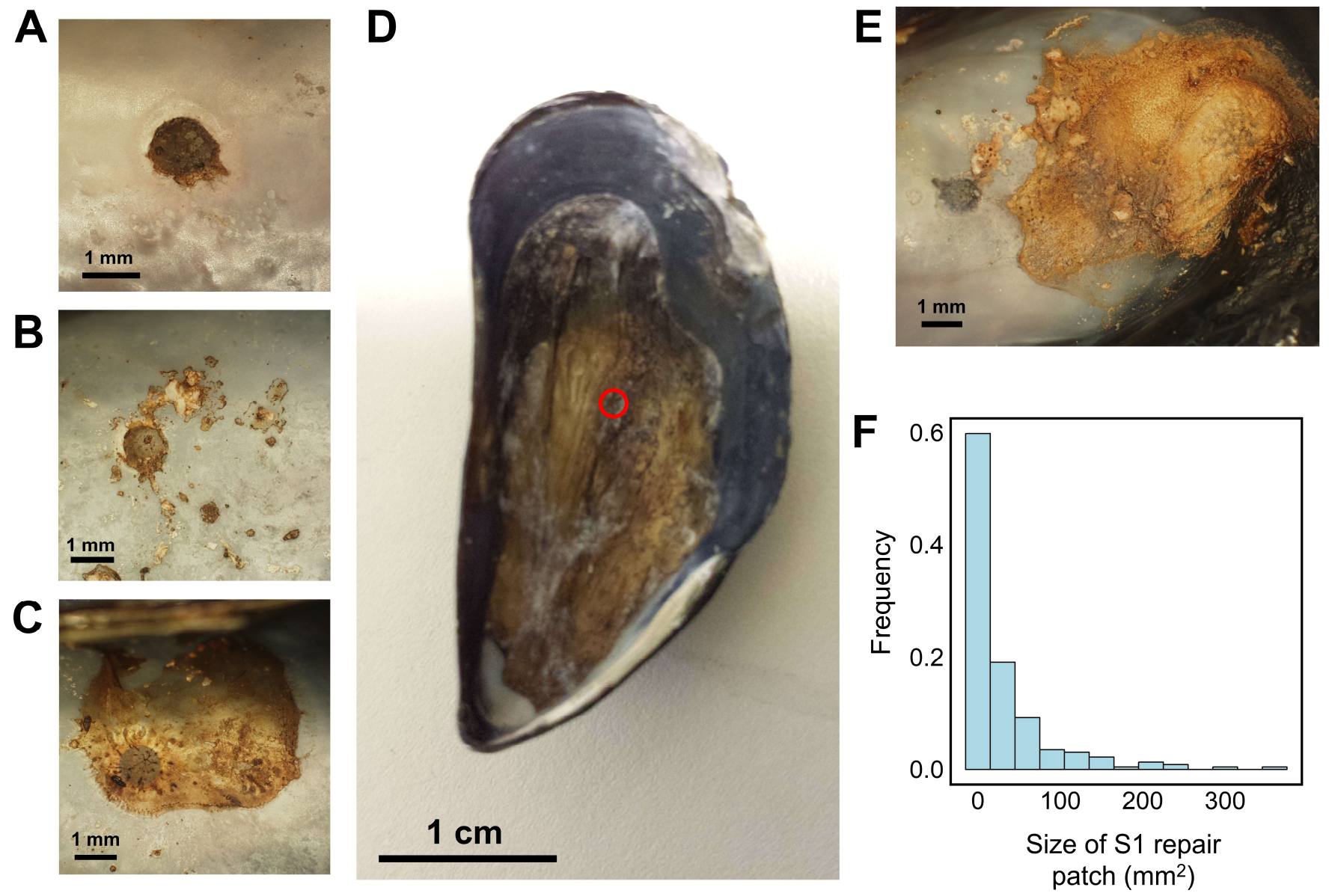

Figure 3. Examples of variable response to shell damage during Stage 1 (S1; M. edulis). Some mussels deposited organic matrix neatly within the shell defect (A), while others applied repair patches over a greater area $(\mathbf{B}, \mathbf{C})$. In rare cases, the organic matrix encompassed the entirety of the valve interior ((D), red circle indicates location of drill hole), while others produced matrix away from the shell injury altogether (E). The frequency distribution of repair patch size during S1 (F).

Throughout field and laboratory experiments, several measurement techniques remained consistent. Whenever a mussel was sampled, the shell length of the major valve axis was measured with vernier calipers (Wiha-41102, $\pm 0.1 \mathrm{~mm}$ ). Mussel condition and reproductive status were also commonly assessed by dissecting and separating gonad and somatic tissue and drying each at $60{ }^{\circ} \mathrm{C}$ until a stable weight was achieved. Condition index (CI) was defined as the ratio of total dry tissue mass to shell length cubed [73], while gonad index (GI) was defined as the ratio of the dry gonad mass to dry somatic tissue mass (Metler Toledo ML54, $\pm 0.01 \mathrm{~g}$ ) as previously described [64].

To assess the progression of shell repair through distinct repair stages, shells were dried at room temperature, photographed with a length standard, and qualitatively scored from 0 to 4 . Shells that had no visible evidence of repair were assigned to Stage 0 (S0). Shells where organic matrix covered drill holes (or was present elsewhere) were considered to be at Stage 1 (S1). Shells at Stage 2 (S2) displayed a mixture of organic and mineral material, while Stage 3 (S3) was assigned when repairs were completely mineralized and rough in texture. Repaired shells at Stage 4 (S4) were considered to be visually similar to the surrounding shell material and resembled the surface shine, color, and texture of nacre. Examples of repaired shells at each stage are provided in Figure 2A.

The size of shell repair patches at each stage was quantified by photographing the shell interior and tracing the outline of the repaired region in Image J [74] to determine its cross-sectional area $\left( \pm 1 \mathrm{~mm}^{2}\right)$. The strength of repaired shell was assessed using an Instron 
5565 material testing frame [75] fitted with a microindentation steel tip (diameter $=0.5 \mathrm{~mm})$. Repairs were approached from the exterior of the shell at $10 \mathrm{~mm} \mathrm{~min}^{-1}$, and the resulting maximum force required to dislodge the repaired region from drill holes was recorded $( \pm 0.01 \mathrm{~N})$. This assay was not designed to be a comprehensive analysis of the material properties of repaired shell, but rather to approximate the effort a predator would have to exert to re-enter the mantle cavity. Finally, the inorganic content (\%) of repaired shell was determined by removing newly deposited material from shell injuries and comparing their mass before and after incineration at $500{ }^{\circ} \mathrm{C}$ for $4 \mathrm{~h} \mathrm{[76].}$

\subsection{Rhode Island: Field Experiment}

The ability of $M$. edulis (shell length $=30-50 \mathrm{~mm}$ ) to repair shell damage was first assessed within mussel bed communities located within the intertidal zone near Black Point, Rhode Island, USA. A $1 \mathrm{~mm}$ diameter hole was carefully drilled in the center of the right valve of mussels in situ without removing mussels from aggregations, using a drill stop of $1 \mathrm{~mm}$ to prevent injury to the internal tissues of the animal. Mussels chosen for inclusion in the experiment were at similar tidal heights (ranging from $0.5 \mathrm{~m}$ above and below MLLW) and within three meters of each other to ensure consistent wave exposure and environmental conditions. After sustaining sublethal shell damage, mussels were sampled over the course of two months (June-July 2003) approximately biweekly (10, 22, 38 , and 51 days). Upon collection, animals were sacrificed and the CI and GI of each were determined; these metrics were compared with an initial sample of nearby mussels taken on the day shell damage was initiated. Shells were visually assessed for shell repair (qualitative score S0-S4), and the cross-sectional area of the repaired region $\left(\mathrm{mm}^{2}\right)$, the force required to dislodge the shell repair $(\mathrm{N})$, and the inorganic content $(\%)$ of newly produced shell were measured using methods as previously described.

\subsection{Washington State: Laboratory Ocean Acidification Experiment}

M. trossulus (shell length $=30-50 \mathrm{~mm}$ ) were collected from Argyle Creek, San Juan Island, WA, USA (48-31'12" N, 123-00'53" W), in March 2012. Upon collection, a subset of mussels was immediately sampled for initial field values of GI and CI. Shell damage was induced in the right valve of remaining mussels as previously described, and individuals were haphazardly placed in one of seven experimental mesocosms that ranged in target $p \mathrm{CO}_{2}$ levels $(400,700,1000,1600,1900,2200,2500 \mu \mathrm{atm})$ at $16^{\circ} \mathrm{C}$ in the Ocean Acidification Environmental Laboratory (OAEL) located at Friday Harbor Laboratories, San Juan Island, WA, USA. Mussels were held in 1.5 L chambers with flow-through, UV-sterilized, and $0.2 \mu \mathrm{m}$ filtered seawater. Chambers were cleaned three times weekly. Mussels were fed Shellfish Diet 1800 algal paste (Reed Mariculture, Campbell, CA, USA) at a daily rate of 5\% of the estimated biomass within each chamber. Mussels were removed from each treatment over the course of a 2.5-month exposure at irregular intervals $(8,15,22,28,43,56,69$ days), and the GI, CI, and cross-sectional area of the repaired shell region, as well as the strength and inorganic content of repaired shell, were determined as previously described.

OA treatments were accomplished through dynamic injection of $\mathrm{CO}_{2}$ using a pH-stat system, following the methods outlined by O'Donnell et al. (2013) [77]. Briefly, a Honeywell UDA2182 process controller and Honeywell Durafet III electrode [78] monitored the $\mathrm{pH}$ (uncertainty $= \pm 0.13 \%$ ) and temperature (uncertainty $= \pm 0.63 \%$ ) of each experimental mesocosm and added $\mathrm{CO}_{2}$ to maintain the $\mathrm{pH}$ at a predefined setpoint calculated from target $p \mathrm{CO}_{2}$ levels using CO2calc [79]. $\mathrm{pH}$ electrodes were calibrated to the total scale using spectrophotometric $\mathrm{pH}$ (Ocean Optics USB4000; Ocean Insight, Toms River, NJ, USA) and were compared to treatment conditions every 3-4 days to ensure the correct calibration was maintained. The salinity of each treatment was measured daily using a sensION 5 conductivity meter (Hach Company, Loveland, CO, USA; uncertainty $= \pm 0.33 \%$ ). Total alkalinity (AT) was measured using SOP 3b from Dickson et al. (2007) every 3-4 days (uncertainty $= \pm 0.33 \%$ ). 
The relationship between AT and salinity established over the course of two years at our field station (AT $=38.856 *$ Salinity $+916.43, \mathrm{R} 2=0.95)$ was used to estimate AT in each mesocosm; results obtained by this method were found to be within $\pm 0.4 \%$ of measured AT values. From estimates of AT and measurements of $\mathrm{pH}$, temperature, and salinity, we calculated the $p \mathrm{CO}_{2}$ ( $\left.\mu \mathrm{atm}\right), \mathrm{CO}_{3}\left(\mu \mathrm{mol} \mathrm{kg}{ }^{-1} \mathrm{SW}\right), \mathrm{HCO}_{3}\left(\mu \mathrm{mol} \mathrm{kg}{ }^{-1} \mathrm{SW}\right)$, aragonite saturation state $\left(\Omega_{\mathrm{ar}}\right)$, and calcite saturation state $\left(\Omega_{\mathrm{ca}}\right)$ of each treatment. The uncertainty associated with each calculated parameter was determined using a Monte Carlo analysis $(i=10,000)$, sampling the random, normal distribution of measurement uncertainty associated with each $\mathrm{pH}, \mathrm{AT}$, temperature, and salinity measurement and propagating them through each calculation. The resulting propagated uncertainty was combined with treatment variability (1 S.D.) by taking the square root of the sum of squares (reported as total uncertainty $\left.\left(\mathrm{U}_{\text {total }}\right)\right)$, following published recommendations [80].

\subsection{SEM and $\mu C T$ Imaging}

Scanning electron micrograph (SEM) images of the surface of repaired shells (M. trossulus) at each repair stage (S1-S4; $400 \mu \mathrm{atm})$, as well as S4 repaired shell produced within the most extreme OA treatment $(2500 \mu \mathrm{atm})$ over 10 weeks, were taken using a Sirion XL30 Field Emission SEM (FEI/Philips, Hillsboro, OR, USA). Shells were rinsed with $\mathrm{dH}_{2} \mathrm{O}$, air dried, flushed with nitrogen, and sputter coated with carbon (10 nm layer thickness) prior to being imaged at $25 \times, 1000 \times$, and $3000 \times$ magnification at $5 \mathrm{kV}$. The elemental composition of the surface of samples was further determined using energy-dispersive X-ray (EDX) spectroscopy using a $100 \mu \mathrm{m}^{2}$ scan area ( $n=3$ mussels per group).

Microtomography ( $\mu \mathrm{CT})$ scans of shells from mussels (M. trossulus) included in OA treatments were taken using a Skyscan 1076 scanner (Bruker, Billerica, MA, USA), imaging shells in $35 \mu \mathrm{m}$ slices at $45 \mathrm{kV}$. Three-dimensional image reconstruction was performed in NRecon (Micro Photonics Inc., Allentown, PA, USA), with further rendering in Drishti [81]. A $1 \mathrm{~mm}$ diameter cylinder was placed on the drill hole of each shell and used to record the mean and maximum grayscale values of scan slices in aggregate. Grayscale values were compared with those of unrepaired shell $1 \mathrm{~mm}$ away from the drill hole.

\subsection{Statistical Analyses}

All statistical analyses were performed in R (Version 4.1.0) using the RStudio IDE (Version 1.4.1717). When applicable, analysis of covariance (ANCOVA) was used to investigate differences in response variables to the duration of exposure (days) and magnitude ( $p \mathrm{CO}_{2}$ targets) of OA treatments. During model construction, the assumptions of normality and homoscedasticity were assessed using the Shapiro test and a visual assessment of Q-Q and residual-fitted plots. To achieve normality, the Johnson transformation was used when necessary [82]. When response variables were expressed as proportions, the logit transformation (log of odds ratio) was used. For significant effects $(\alpha=0.05)$, the agricolae package was used to perform pairwise comparisons of groups using the Tukey HSD post hoc test [83]. For the comparison of qualitative repair scores, the distribution of mussels within each stage was compared with a chi-squared test, using the $400 \mu$ atm treatment values as the expected values.

\section{Results}

\subsection{Rhode Island: Field Experiment}

Evidence of gastropod predation within mussel beds varied significantly during monthly field sampling of intertidal sites, with as many as $8 \%$ of mussels (M. edulis, $n=50$, 1998-2001) within bed populations carrying shell damage in a given month (Figure 1B). When shell damage was intentionally induced in a subset of individuals within a population, mussels progressed steadily through each repair stage (S0-S4) over a 51-day period (Figure 2A,C). Ten days after shell damage was induced, 70\% of mussels had entered the first stage of shell repair (S1) and successfully closed drill holes by applying an organic membrane over the opening (examples from $M$. trossulus provided in Figure 3). These re- 
sults matched laboratory assays wherein it took $M$. trossulus $(n=25) 11$ days for all mussels to reach S1 (Figure 2B). Following the closure of the shell opening, 86.6\% of mussels were at S2 after 22 days, and 80\% were at S3 after 38 days (Figure 2C).

Significant changes in the material and biomechanical properties of repaired shell were observed as mussels progressed through each repair stage. The inorganic content $(p<0.001$, Figure 2D) and force required to dislodge repaired shell material $(p<0.001$, Figure 2E) significantly increased as mussels (M. edulis) remained within the intertidal zone after shell injury by $+83 \%$ and $+346 \%$ (comparing 10 to 51 days), respectively. For both measured parameters, the hardening of the repaired region corresponded with the transition from S1 to S2 (Figure 2C-E). The relationship between repair stage and the physical properties of repaired shell was further validated by pooling data from field experiments (M. edulis) and laboratory studies discussed in the following section (M. trossulus); repair stage was positively correlated with inorganic content $(p=0.012$; Figure $2 \mathrm{~F})$ and force $(p=0.032$; Figure $2 \mathrm{G}$ ). The strength of repaired shell and inorganic content were also positively correlated (loess regression) with each other when compared across both species, with inorganic content explaining $42 \%$ of the variance observed in force $(p<0.001$, Figure $2 \mathrm{H})$.

At the end of the field experiment, the appearance of repaired shell resembled that of surrounding shell, with all mussels proceeding to at least S3 after 51 days; in this endpoint population, $45 \%$ of repairs were in S4 (Figure 2C). However, mechanical testing demonstrated that repaired shell at stages S2, S3, and S4 required similar forces to dislodge repair patches (Figure 2E), indicating that perhaps more time is needed to produce a material with a similar structural integrity to undamaged shell.

\subsection{Washington State: Ocean Acidification Shell Repair Experiment}

Laboratory experiments employed seven OA treatments, with measured $\mathrm{pH}$ values ranging from 7.29 to 7.95 (total scale, Table 1) and calculated $p \mathrm{CO}_{2}$ levels ranging from 483 to $2458 \mu \mathrm{atm}$ (Table 2). OA did not significantly affect whether mussels were able to repair damaged shell, with no observed impact of $p \mathrm{CO}_{2}$ on the proportion of mussels that fully mineralized repaired shell (reached S3 or S4) after 4 weeks ( $p=0.53$, Table S1). All mussels closed drill holes irrespective of treatment, with no impact of $p \mathrm{CO}_{2}(p=0.64)$ or length of treatment exposure (time, $p=0.57$ ) on the size of the S1 repair patch (Table S3). Repair patches were generally proportional to the degree of shell damage, neatly covering the drill hole in $60 \%$ of cases (Figure 3F). However, significant overgrowth of the repair patch did occur, resulting in organic matrix deposition within the entire valve interior (Figure 3D) and repair away from the shell defect in rare instances (Figure 3E).

Table 1. Measured seawater carbonate parameters during OA treatments and their respective variability ( $\pm 1 \mathrm{SD})$. Measurement uncertainties for each parameter were as follows: temperature $(\mathrm{T}$; $0.63 \%)$, salinity $(\mathrm{S} ; 0.33 \%), \mathrm{pH}(0.13 \%)$, and total alkalinity $\left(\mathrm{A}_{\mathrm{T}} ; 0.19 \%\right)$.

\begin{tabular}{ccccc}
\hline$p \mathbf{C O}_{\mathbf{2}}$ Target & $\mathbf{T}\left({ }^{\circ} \mathbf{C}\right)$ & Salinity & $\mathbf{p H}$ (total) & $\mathbf{A}_{\mathbf{T}}(\boldsymbol{\mu \mathbf { m o l } \times \mathbf { k g S W } )}$ \\
\hline 400 & $15.8 \pm 0.1$ & $30.0 \pm 0.2$ & $7.95 \pm 0.03$ & $2079 \pm 7$ \\
700 & $16.1 \pm 0.5$ & $29.9 \pm 0.3$ & $7.77 \pm 0.02$ & $2083 \pm 8$ \\
1000 & $15.9 \pm 0.2$ & $30.2 \pm 0.1$ & $7.64 \pm 0.02$ & $2080 \pm 10$ \\
1600 & $16.0 \pm 0.3$ & $30.4 \pm 0.2$ & $7.46 \pm 0.02$ & $2086 \pm 7$ \\
1900 & $16.0 \pm 0.2$ & $30.0 \pm 0.1$ & $7.38 \pm 0.06$ & $2080 \pm 6$ \\
2200 & $16.0 \pm 0.4$ & $29.8 \pm 0.2$ & $7.31 \pm 0.03$ & $2078 \pm 5$ \\
2500 & $15.9 \pm 0.1$ & $30.4 \pm 0.3$ & $7.29 \pm 0.03$ & $2090 \pm 9$ \\
\hline
\end{tabular}


Table 2. Calculated seawater parameters over the course of OA treatments and their respective uncertainties. The total uncertainty $\left(U_{\text {total }}\right)$ for each calculated parameter is reported as the combination of propagated measured uncertainties as reported in Table 1 and the variability of each parameter over the course of each experiment.

\begin{tabular}{cccccc}
\hline $\begin{array}{c}p \mathrm{CO}_{2} \\
\text { Target }\end{array}$ & $\begin{array}{c}p \mathrm{CO}_{2} \\
(\mu \mathbf{a t m})\end{array}$ & $\begin{array}{c}\mathrm{CO}_{3}(\boldsymbol{\mu m o l} \times \\
\mathbf{k g S W})\end{array}$ & $\begin{array}{c}\mathbf{H C O}_{3}(\mu \mathbf{m o l} \\
\times \mathbf{~ k g S W})\end{array}$ & $\boldsymbol{\Omega}_{\mathrm{Ar}}$ & $\boldsymbol{\Omega}_{\mathrm{Ca}}$ \\
\hline 400 & $483 \pm 64$ & $110 \pm 17$ & $1807 \pm 38$ & $1.74 \pm 0.26$ & $2.73 \pm 0.40$ \\
700 & $769 \pm 100$ & $77 \pm 13$ & $1892 \pm 31$ & $1.21 \pm 0.22$ & $1.90 \pm 0.32$ \\
1000 & $1062 \pm 140$ & $58 \pm 10$ & $1939 \pm 27$ & $0.91 \pm 0.16$ & $1.43 \pm 0.25$ \\
1600 & $1652 \pm 215$ & $39 \pm 7$ & $1986 \pm 21$ & $0.62 \pm 0.11$ & $0.97 \pm 0.18$ \\
1900 & $2009 \pm 372$ & $34 \pm 7$ & $2000 \pm 22$ & $0.53 \pm 0.11$ & $0.82 \pm 0.18$ \\
2200 & $2365 \pm 317$ & $28 \pm 5$ & $2013 \pm 19$ & $0.44 \pm 0.08$ & $0.69 \pm 0.13$ \\
2500 & $2458 \pm 340$ & $27 \pm 7$ & $2016 \pm 20$ & $0.43 \pm 0.09$ & $0.67 \pm 0.14$ \\
\hline
\end{tabular}

Repaired Shell
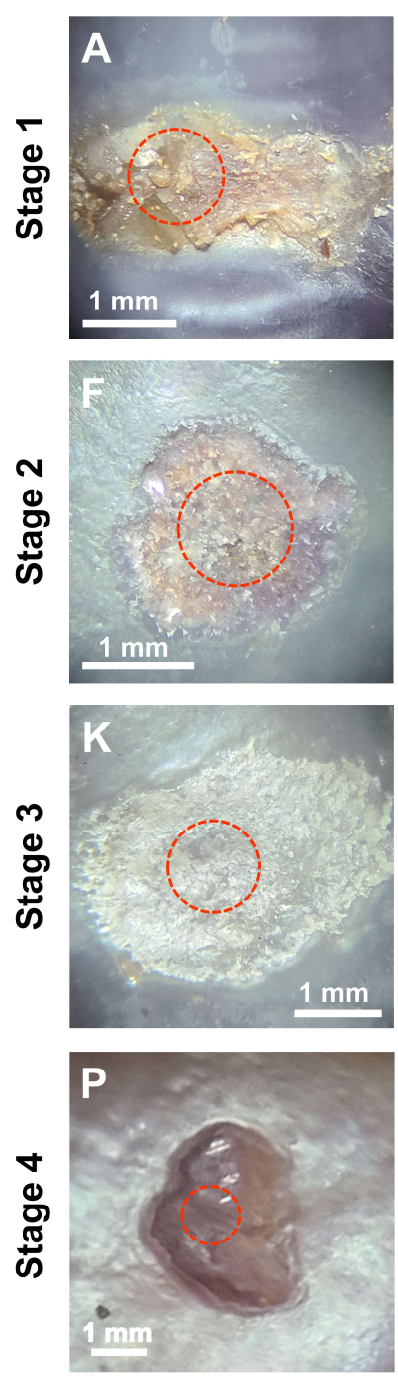
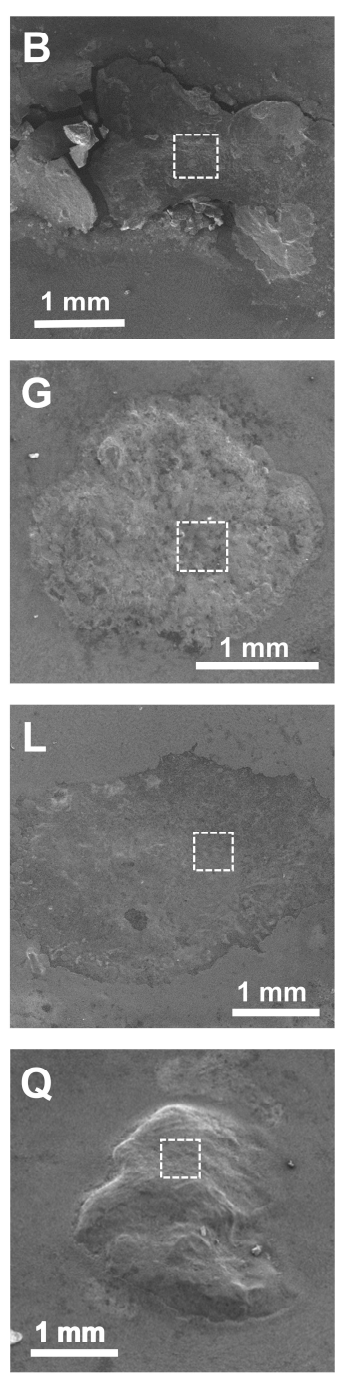
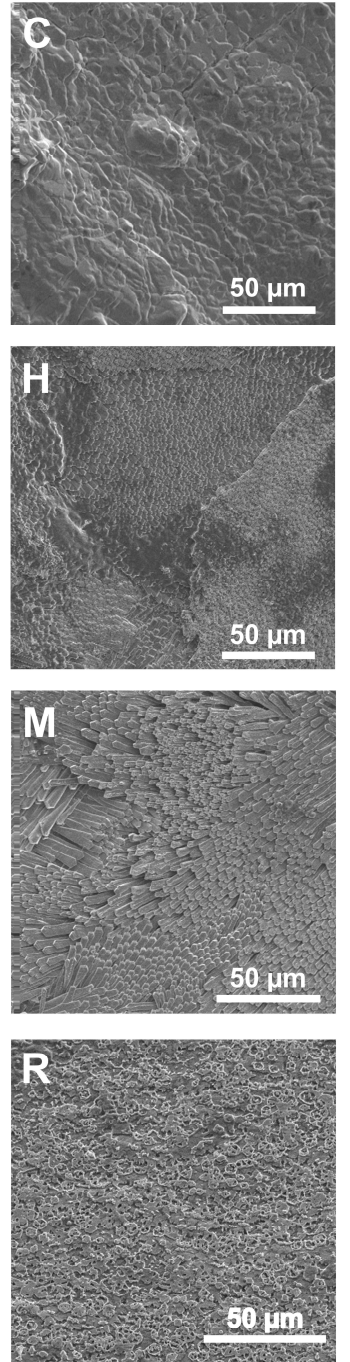

\section{Unrepaired Shell}
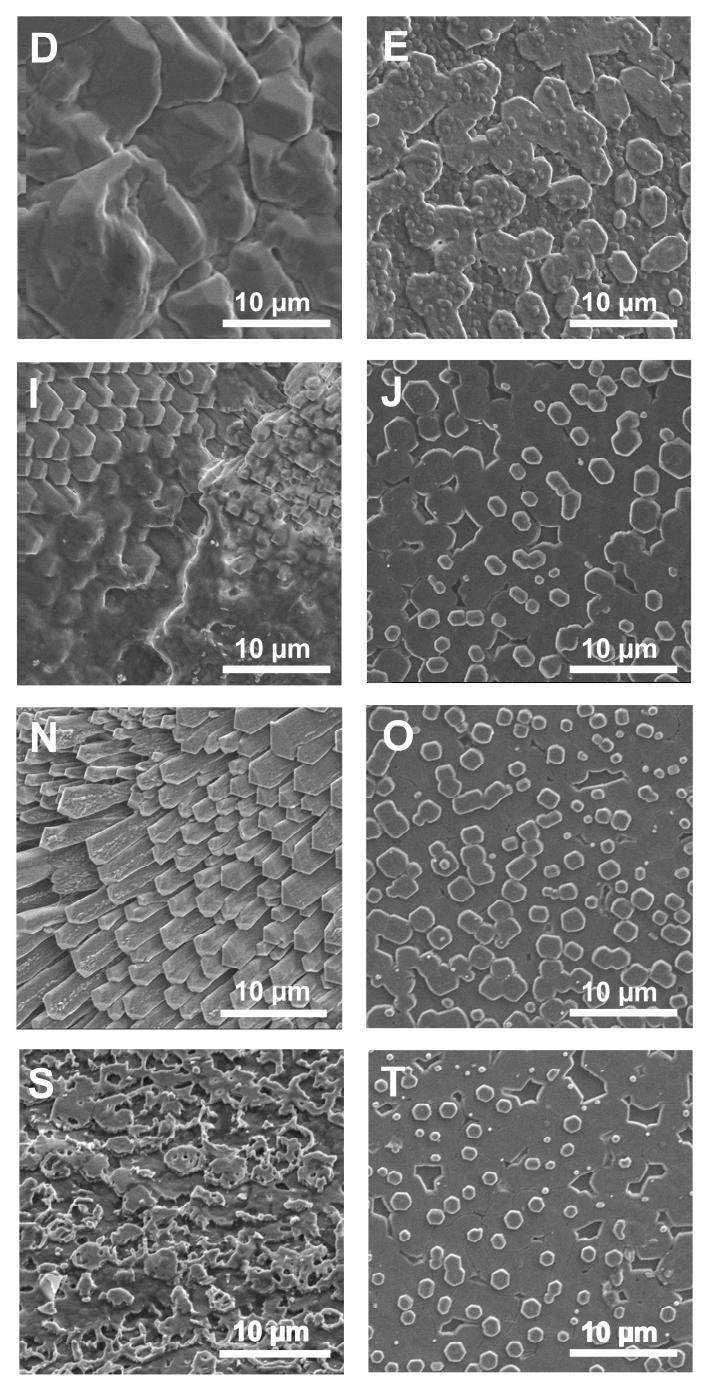

Figure 4. Light and SEM images of repaired drill holes at Stage $1(\mathrm{~S} 1 ;(\mathbf{A}-\mathbf{E}))$, Stage $2(\mathrm{~S} 2 ;(\mathbf{F}-\mathbf{J}))$, Stage 3 (S3; (K-O)), and Stage $4(\mathrm{~S} 4 ;(\mathbf{P}-\mathbf{T}))$, from the valve interior of mussels (M. trossulus) exposed to $400 \mu$ atm $p \mathrm{CO}_{2}$ for 15, 28, 43, and 69 days, respectively. Red circles represent the location of drill holes within light microscopy images; white boxes are the scan area used for magnified SEM images. Images for each repair stage were each taken from the same mussel; image magnification for SEM images increases from left to right within each row $(25 \times, 1000 \times, 3000 \times)$. The last panel within each row is an image of unrepaired shell away from the repair within the same individual $(3000 \times)$. 
SEM imaging paired with EDX analysis of the interior surface of repaired shell produced by mussels within the $400 \mu$ atm treatment demonstrated that significant differences in shell microstructure (Figure 4) exist across repair stages. $\mu$ CT imaging of shells at S3 and S4 also suggested that repaired shell had similar grayscale values to unrepaired shell (but not throughout), appeared thinner in cross-section, and was often anchored to the interior shell away from the drill hole edge (Figure 5C,D). No evidence of membrane mineralization was observed at S1 (Figure 4A-D), while a mixture of protein and short calcite fibers was observed at S2 (Figure 4F-I). At S3, the entire repair was made up of elongated calcite fibers (Figure $4 \mathrm{~K}-\mathrm{N}$ ), which were covered by a layer of irregularly shaped aragonite tablets in S4 (Figure 4P-S). Tablets formed in S4 remotely resembled the nacreous layer present in unrepaired shell (Figure 4E,J,O,T), although with a pock-marked surface and an irregular orientation. A significant difference between the surface elemental composition of repaired shell and that of unrepaired shell was only observed in stages $S 1\left(X^{2} 8100=192, p<0.001\right)$ and S2 $\left(X^{2} 8100=7413, p<0.001\right)$ (Figure 7C).
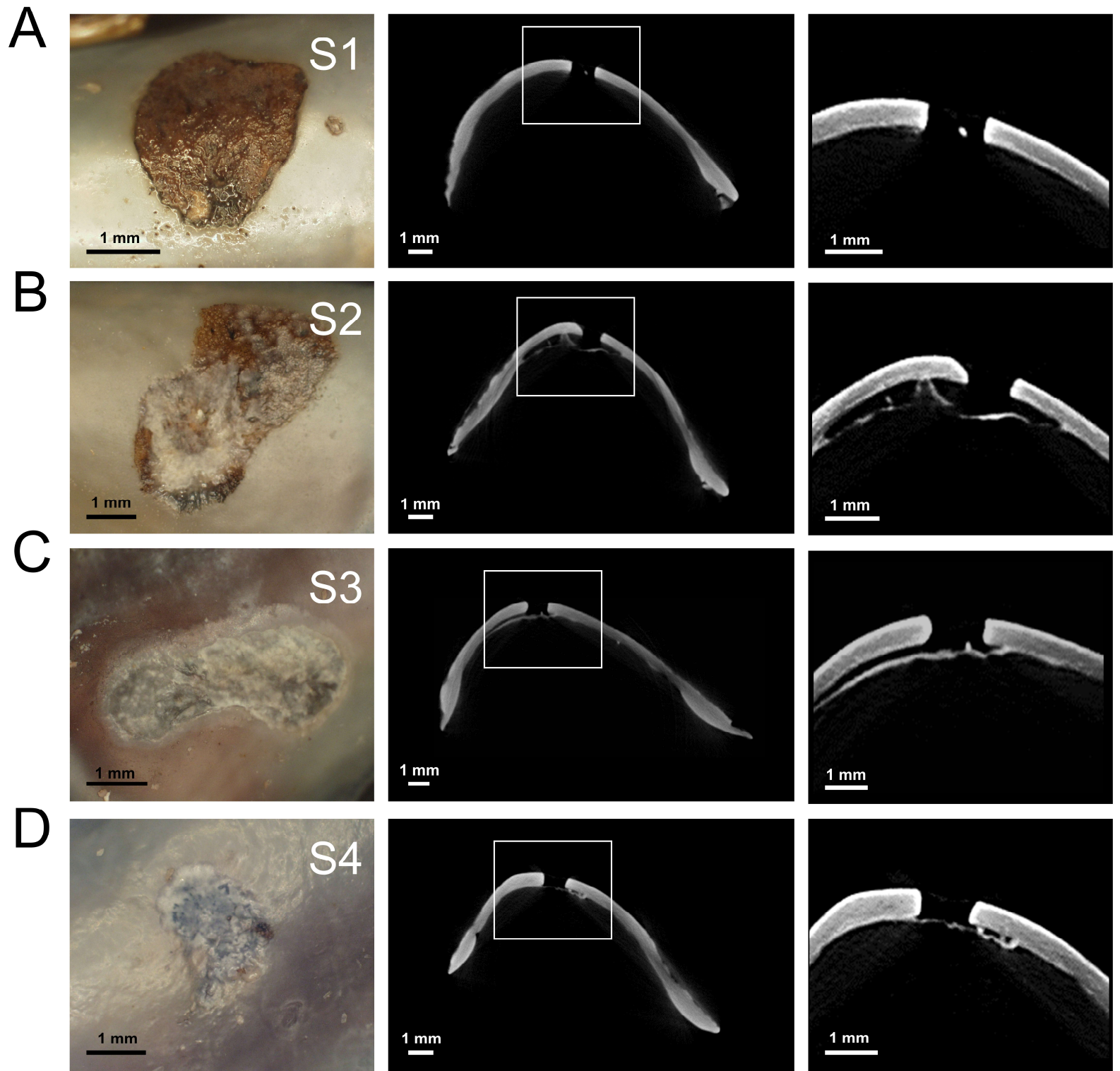

Figure 5. Representative photographs and $\mu \mathrm{CT}$ images of repaired drill holes at Stage 1 (S1; (A)), Stage 2 (S2; (B)), Stage 3 (S3, (C)), and Stage 4 (S4, (D)). Images are from mussels within laboratory experiments (M. trossulus; $400 \mu$ atm $p \mathrm{CO}_{2}$ ). 
While OA did not prevent mussels from closing shell injuries or mineralizing repaired shell, the severity of $p \mathrm{CO}_{2}$ exposure and the time spent within treatments significantly impacted the inorganic content (OA: $p<0.001$, time: $p<0.001$; Table S3, Figure 6B) and the force required to dislodge repair patches (OA: $p<0.001$, time: $p=0.02$; Table S3, Figure 6C). Similar results were observed when analyses were constrained to only include mussels after 10 weeks within treatments (end-point only). After 10 weeks of OA exposure, significantly fewer animals reached S3 or S4 in treatments where $p \mathrm{CO}_{2}$ was greater than $1500 \mu \mathrm{atm}$ (Figure 6D; $400 \mu$ atm control). However, while $p \mathrm{CO}_{2}$ did have a significant effect on the inorganic content of repaired shell ( $p=0.013$, Table S2, Figure 6E), no effect was observed on the force required to dislodge repair patches $(p=0.263$, Table S2, Figure 6F). Similarly, no effect was observed on the surface elemental composition of S4 repaired shell produced under exposure to $2500 \mu \mathrm{atm} p \mathrm{CO}_{2}$ for 10 weeks when compared with unrepaired shell from the same animal $\left(X^{2} 8100=0.87, p=0.99\right)$ or conspecifics that produced S4 shell in the $400 \mu$ atm treatment $\left(X^{2} 8100=1.99, p=0.98\right.$; see Figure $\left.7 C\right)$. Moreover, no effect of OA was observed on the mean ( $p=0.85$, Figure $8 \mathrm{C}$ ) or maximum $(p=0.56$, Figure $8 \mathrm{D})$ grayscale values approximating the shell density of the repaired region collected from $\mu \mathrm{CT}$ scans (Table S4).
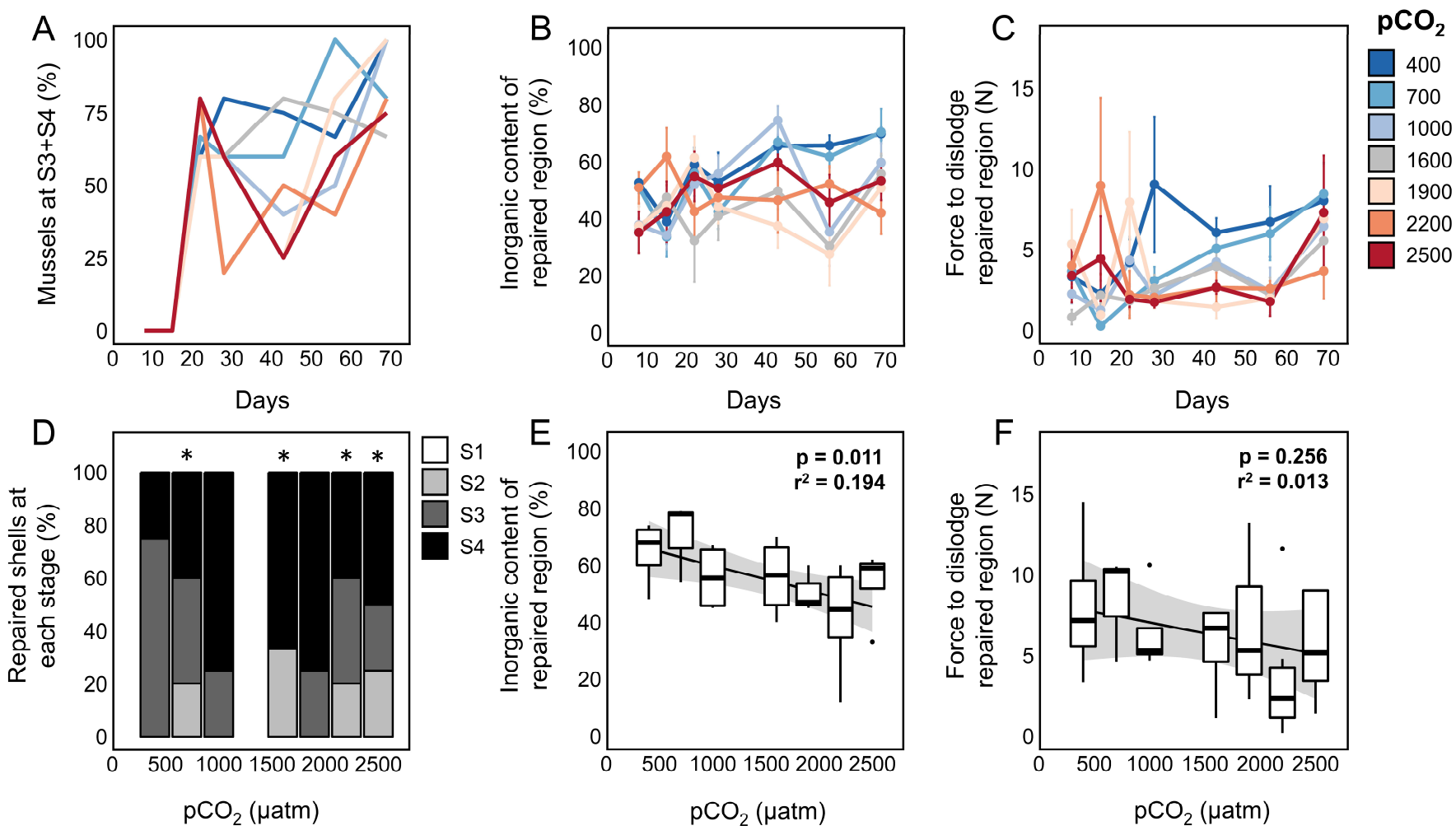

Figure 6. (A) Proportion of mussels (M. trossulus) that produced mineralized shell (reached S3 or S4) in response to shell damage within each OA treatment. (B) Inorganic content of excised repaired shell from mussels within each OA treatment. (C) The force required to dislodge repaired regions produced in each OA treatment. Proportion of mussels at each repair stage (D), the inorganic content of repaired regions (E), and force to dislodge repaired regions (F) after 10 weeks within each OA treatment. Data are from 4-8 mussels per treatment per time point. Asterisks mark treatments that were statistically different from the $400 \mu$ atm control.

The condition $(p<0.001)$ and gonad $(p=0.008)$ indices of mussels universally decreased over 10 weeks under laboratory conditions (Table S5, Figure S2A,D). Mussel condition $(p=0.017)$, but not reproductive condition $(p=0.814)$, was significantly affected by $p \mathrm{CO}_{2}$, and no interaction with time in treatment was detected ( $p=0.645$, Table S3). When comparing the initial and final conditions and gonad indices under experimental conditions, 
a significant impact of $p \mathrm{CO}_{2}$ on $\mathrm{CI}(p<0.001)$ and $\mathrm{GI}(p=0.012)$ was observed, with no decrease in either metric observed in field populations over the same time period (Table S5, Figure S1). However, neither CI nor GI was correlated with the force to dislodge repaired regions (CI: $p=0.435$; GI: $p=0.690$ ) or their inorganic content (CI: $p=0.989$; GI: $p=0.619$ ), with no observed clustering observed with $p \mathrm{CO}_{2}$ treatment (Figure S2).
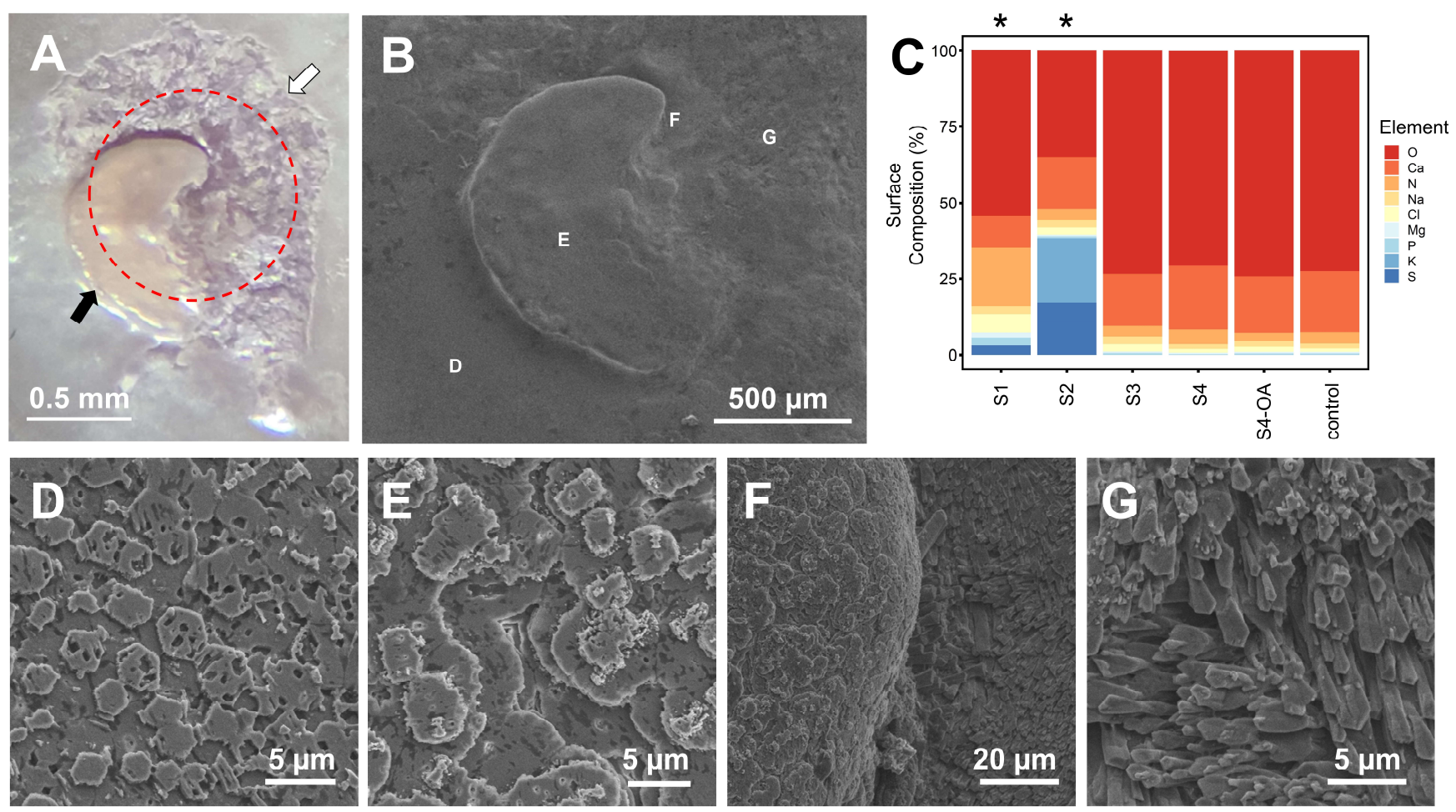

Figure 7. Light (A) and SEM (B,D-G) microscopy images of a repaired drill hole ((A), red circle) from the valve interior of a mussel (M. trossulus) exposed to $2500 \mu$ atm $p \mathrm{CO}_{2}$ for 10 weeks, with evidence of repaired shell at both Stage 3 (S3; white arrow) and Stage 4 (S4; black arrow). (C) Elemental composition (\%) of the interior valve shell surface at each repair stage (S1-S4; $400 \mu$ atm $p \mathrm{CO}_{2}$ ), S4 shell produced under ocean acidification for 10 weeks (S4-OA; $2500 \mu$ atm $p \mathrm{CO}_{2}$ ), and unrepaired shell (control) as determined through energy-dispersive X-ray (EDX) spectroscopy analysis (100 $\mu \mathrm{m}^{2}$ scan area; $n=3$ mussels per group). SEM images of unrepaired (D) and S4 repaired shell (E) confirmed the presence of a nacreous layer, although with different surface topographies. (F) SEM image of the transition between S4 (left) and S3 (right) repaired shell. (G) SEM image of S3 repaired shell resembling the calcite crystals commonly found in the oblique prismatic layer. Letters D-G within panel B indicate the locations of images within panels D-G. Asterisks indicate stages where the elemental composition was statistically different from that of the control. 

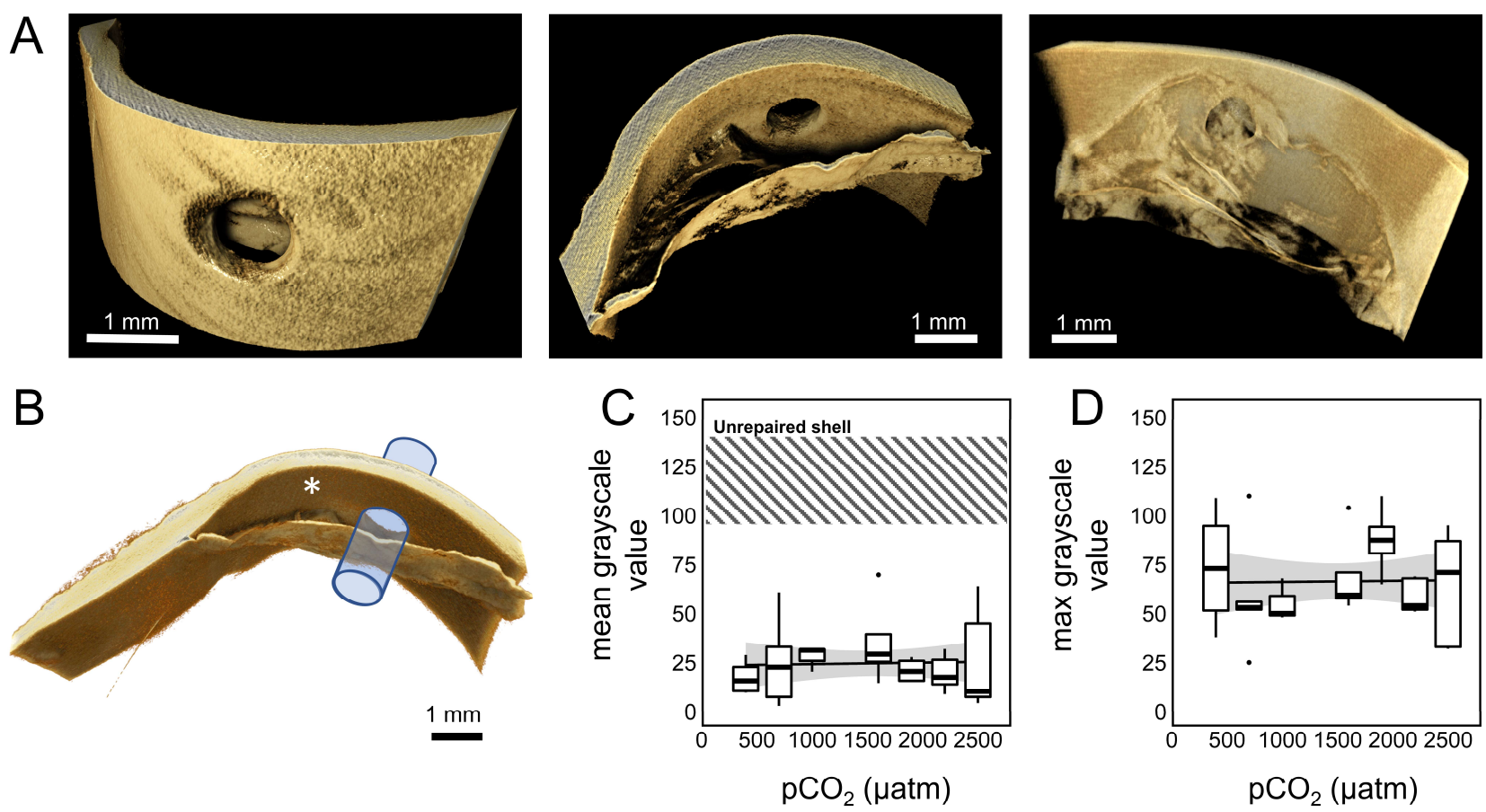

Figure 8. (A) The 3D rendering of a drill hole and deposited shell material constructed from $\mu \mathrm{CT}$ scan slices. Images represent three perspectives of the same shell repair from a single mussel ( $M$. trossulus) held within the $400 \mu$ atm $p \mathrm{CO}_{2}$ for 10 weeks. (B) Cylindrical volume used for analysis; asterisk marks approximate location used for control measurements of unrepaired shell. The mean (C) and maximum (D) grayscale values within sampled cylinders after 10 weeks within OA treatments ( $n=4-8$ mussels per treatment).

\section{Discussion}

Here we describe the process of shell repair in two mytilid mussel species following sublethal shell damage that penetrated the mantle cavity away from the shell margin, as well as the effect of ocean acidification (OA) on the deposition rate, structure, composition, and integrity of repaired shell. In both field and laboratory assays, mussels began to mineralize shell injuries within weeks, with repaired shell transitioning through repair stages defined by distinct changes in color, texture, and surface microstructure (S0-S4; Figures 2A and 4). Following damage, an organic membrane first covered the damaged area (days 1-15), followed by the deposition of calcite crystals (days 22-43) and aragonite tablets (days 51-69). Repair stage was also positively correlated with inorganic content, structural integrity, and calcium composition (Figures 2 and 7C). Considering end-point samples only, the ability of mussels to seal and mineralize shell breaches was not impacted by environmental $p \mathrm{CO}_{2}$ (Table S1, Figure 6A), and no effect of OA was observed on the strength (Figure 6F), elemental composition (Figure 7C), microstructure (Figure 7D-G), or $\mu \mathrm{CT}$ grayscale values (Figure 8 ) of repaired shell after 10 weeks under laboratory conditions. However, when mussels from all time points across treatments were included in analyses, significant interactions between $p \mathrm{CO}_{2}$, the length of exposure to treatment conditions, repair strength, repair inorganic content, and mussel physiological condition were observed (Table S3, Figure 6). These results suggest that, while OA (up to $2500 \mu \mathrm{atm}$ ) does not prevent mussels from repairing shell injuries, both $p \mathrm{CO}_{2}$ exposure and shell damage likely elicit stress responses that impose energetic constraints on mussel physiology.

During S1, an organic membrane quickly covered drill holes. Incineration with muffle furnace (Figure 2D), $\mu \mathrm{CT}$ imaging (Figure 5), and EDX composition analysis (Figure 7C) confirmed that the membrane was not mineralized and did not have similar $\mu \mathrm{CT}$ grayscale values or a mineral composition that resembled any other stage. Membranes were also anchored to the shell around, rather than within, drill holes (Figures 5 and 8A). While a full 
characterization of the components of the shell-repair membrane in Mytilus remains to be undertaken, proteomic analyses of shell [84-86] and the extrapallial fluid $[87,88]$ in multiple mytilid species suggest that the membrane is composed of a variety of polysaccharides, glycoproteins, and shell matrix proteins (SMPs). While only a minor component of the shell matrix, SMPs play an important role in $\mathrm{CaCO}_{3}$ nucleation, growth, and polymorph determination $[89,90]$, and their expression has been shown to be induced in the central mantle following shell injury [47]. Further, transcriptional analysis of the mantle following shell damage within $M$. edulis has identified transcripts that encode proteins with domains found in shell matrix proteins (SMPs), immune response proteins, and other proteins involved in biomineralization [45].

Significant variability was observed in the initial response to shell injury across mussels sampled, irrespective of species or $p \mathrm{CO}_{2}$ treatment. Organic membranes typically covered drill holes but varied widely in their size and shape (Figure 3A-E); $10 \%$ of mussels produced a patch $100 \times$ greater than the drill hole diameter (Figure $3 \mathrm{~F}$ ), and in rare instances, organic matrix was deposited away from shell damage altogether (Figure 3E). To our knowledge, variability in the localization of the repair process of this magnitude has not been previously reported. One possible explanation for this variation could be that, while great lengths were taken to standardize the depth with which drill holes were generated, variation in shell thickness may have resulted in different degrees of tissue damage. Alternatively, nonlocalized repair could be the result of the nonspecific deposition of shell matrix proteins (SMPs) that act as nucleation sites during calcite and aragonite formation $[45,47,91]$. While it is likely that the transcriptional response of mantle tissue to shell damage will be greatest next to the shell injury [31], the factors that govern how SMPs are deposited onto damaged shell after extrusion into the extrapallial fluid remain unclear. The nonlocalized and oversized repair observed within some mussels within this study could point to this process being more generalized than previously thought, or mediated by some yet unknown property of the shell interior.

During shell biomineralization, calcium carbonate precipitation onto the organic matrix acts as a precursor to aragonite formation [30,92]. In this study, calcite filaments developed during S2 and became ubiquitous and elongated during S3 (days 22-43, Figure 4L-N), resembling the calcitic fibrous layer observed in $M$. galloprovincialis as described by Checa et al. (2014) [39]. This layer was then laminated with aragonite tablets (days 51-69; see Figure 4Q-S) that had a pock-marked, irregular surface topography when compared with unrepaired shell (e.g., see Figure 4T). Irrespective of individual variation in organic membrane size, the strength, inorganic content, and elemental calcium composition of repaired shell increased as it transitioned through each stage (Figures 2, 5 and $7 \mathrm{C}$ ). As membranes were mineralized, the force required to dislodge repair patches from the shell exterior also increased, but did not approach that of unrepaired shell (Figure 2E; flat plate compression testing, George et al., unpublished data). The impact of shell repair on the mechanical strength of shells has been investigated in a number of mollusk species. In studies of gastropods that employed flat plate compression testing, mechanical stress produced cracks that propagated along growth lines rather than repaired shell, resulting in no impact on shell integrity $[36,93]$. Similarly, M. californianus has been found to repair shell fatigue damage, with repaired shell often exceeding the strength of unrepaired shell after 4 weeks [37]. However, these results are not comparable as the mechanical testing employed in this study was designed to estimate the effort required of a secondary predator to reach the mantle cavity through the repaired material. Future studies would benefit from employing multiple mechanical testing strategies to ascertain whether repaired drill holes impact the ability of shell to protect from different predators.

The repair chronology observed in this study is in agreement with other investigations of shell repair in a number of bivalve species [30,32,94]. Similarly, a study by Hüning et al. (2016) that employed a drill-based shell damage assay in M. edulis described three repair stages in which a repair membrane was evident at day 20, calcite crystal accumulation after 29 days, and aragonite tablet formation after 36 days [47]. While dividing the repair process 
into three stages may accurately describe the transition from a protein membrane to the two mineral polymorphs commonly seen during biomineralization, significant differences in the inorganic content (Figure $2 \mathrm{~F}$ ), microstructure (Figure 4F-I), and elemental composition (Figure 7C) were observed in this study during the transition between membrane formation and mineralization (S2). These results suggest that future studies would benefit from a more granular investigation of the repair process to accurately characterize the material and mechanical differences of shell within and between repair stages.

The morphology [58], chemical composition [95], microstructure [57,96], and mechanical properties [54,97] of mussel shells have been shown to be impacted by ocean acidification. OA has been proposed to impact shell formation through both direct and indirect mechanisms, including a decrease in carbonate ion $\left(\mathrm{CO}_{3}{ }^{2-}\right)$ availability with declining $\mathrm{pH}[56,61]$, pH-induced metabolic stress that disrupts the intercellular transport mechanisms that support the production of calcium carbonate [62], decreased calcification rates [57], and an increase in the cost of calcification [98]. In this study, M. trossulus repaired damaged shell within seven $p \mathrm{CO}_{2}$ treatments ranging from 400 to $2500 \mu$ atm for 10 weeks. No direct impact of OA was observed on the timing of the shell repair process, and all mussels reached S1 after 22 days regardless of OA treatment (Figure 6A). Looking at endpoint samples (69 days of OA exposure), there was also no evidence of an impact of OA on the strength (Figure $6 \mathrm{~F}$ ) or $\mu \mathrm{CT}$ grayscale values (Figure 8) of repaired shell; a significant impact on the inorganic content was observed (Figure 6E). Mussels were able to reach S4 and produce aragonite tablets in the most extreme OA treatment (2500 $\mu \mathrm{atm})$; tabloid structures were similar in both structure and composition to unrepaired shell produced within the acidified and control treatments (Figures 4 and 7). When all time points from all treatments were included, significant interactions between $p \mathrm{CO}_{2}$ and the time spent in each OA treatment was observed for both the strength (force to dislodge) and inorganic content of repaired shell (Table S1), as well as a trend of more mussels remaining in S2 after 10 weeks in high $p \mathrm{CO}_{2}$ treatments (Figure 6D).

Shell production is an important and cost-intensive process, with estimates that biomineralization can account for up to $22.3 \%$ of the energy budget of $M$. trossulus [99], with an estimated cost of $29 \mathrm{~J} \mathrm{mg}^{-1}$ of organic matrix $[59,60]$. However, there is also substantial evidence that adult mussels can produce shell under physiologically stressful conditions, and many species persist in upwelling zones where $\mathrm{CO}_{2}$-rich waters can lead to calcium carbonate saturation states well below 1 [100]. Subsequent observations of the total calcium carbonate production of mussel beds within these regions also suggest that the degree to which OA impacts shell production strongly depends on habitat food density (particulate organic carbon (POC) $[98,101]$ and pales in comparison to the effect of warming [54]. In the context of shell repair, robust expression of SMP candidate genes in the central mantle has also been shown to be maintained under exposure to $4000 \mu \mathrm{atm}$ for 8 weeks [102]. In our laboratory experiment, all mussels were fed 5\% of their wet body mass in algae daily, delivered at a concentration of 3000-10,000 cells $\mathrm{mL}^{-1}$ with peristaltic pumps at regular intervals. This amount of food is consistent with previous studies where mussels have maintained and even gained tissue mass over the course of months [77]. However, the condition of mussels within our experiment, as denoted by the ratio of grams of dried tissue to shell length cubed (CI), decreased as both a function of $p \mathrm{CO}_{2}$ treatment $(p=0.008)$ and time $(p=0.001)$ with an interaction that was also significant ( $p=0.030$, Table S5). As a point of comparison, wild populations of mussels that did not undergo shell damage over this same time period did not experience a significant decrease in either physiology condition or gonad index (Table S5, Figure S1). To address this issue, future studies would benefit from the inclusion of additional controls to tease apart the energetic demand placed on mussels by the shell repair process, $\mathrm{OA}$, and their interaction.

Our results suggest that mussels within the intertidal zone routinely survive predation attempts that result in shell damage (up to $8 \%$ of $M$. edulis field populations, see Figure 1) and are capable of quickly closing and mineralizing repair patches despite variation in environmental $p \mathrm{CO}_{2}$. Additionally, the decline in physiological condition of mussels within 
all laboratory treatments supports the conclusion that shell repair is energy-intensive. Given its importance to survival across a wide range of molluscan species, shell repair may impose energetic limitations on other physiological processes such as growth or reproduction [103]. Our results suggest that in areas where bivalves sustain a high rate of shell damage, it is possible that the costs associated with shell repair could compound over time, preventing smaller individuals from quickly surpassing the size range in which larger predators (e.g., sea stars, crustaceans) can handle them [104]. To tease apart these interactions, future work would benefit from integrating biomechanical, proteomic, and transcriptomic techniques to describe the shell repair process in different environmental conditions and under different degrees of food limitation.

Supplementary Materials: The following supporting information can be downloaded at: https: / / www.mdpi.com/article/10.3390/jmse10030359/s1; Figure S1: Mussel physiological and reproductive condition; Figure S2: Impact of mussel condition and reproductive status on shell repair; Table S1: Impact of $p \mathrm{CO}_{2}$ on shell repair timing (ANCOVA); Table S2: Impact of $p \mathrm{CO}_{2}$ and CI on repaired shell properties within endpoint populations (ANCOVA); Table S3: Impact of $p \mathrm{CO}_{2}$ on a variety of physiological and shell parameters across all treatments and sampling timepoints (ANCOVA); Table S4: Impact of $p \mathrm{CO}_{2}$ on the mean and max grayscale $\mu \mathrm{CT}$ grayscale values of endpoint samples (ANOVA); Table S5: Comparison of initial and final mussel physiological and reproductive condition (ANOVA).

Author Contributions: M.N.G., M.J.O. and E.C. conceived of the study. M.C. and E.C. conducted mussel bed surveys and performed the shell repair field assay using M. edulis. M.N.G. and M.J.O. conducted the ocean acidification experiment with $M$. trossulus and completed mechanical testing, material composition assays, and $\mu \mathrm{CT}$ analyses. M.N.G. conducted the SEM study. M.N.G. and E.C. performed data analysis and wrote the manuscript. All authors have read and agreed to the published version of the manuscript.

Funding: This work was supported by NSF award \#DBI-0829486 to K. Sebens, T. Klinger, and J. Murray and by NSF awards \#EF-104113 and OCE-2050273 to E. Carrington. Part of this work was conducted at the Molecular Analysis Facility, a National Nanotechnology Coordinated Infrastructure site at the University of Washington which is supported in part by the National Science Foundation award ECC-1542101, the University of Washington (UW), the Molecular Engineering and Sciences Institute, the Clean Energy Institute, and the National Institutes of Health. Additional support was provided by a UW Turn Point Faculty Fellowship to E. Carrington.

Data Availability Statement: Data are archived under project \#2250 at www.bco-dmo.org (accessed on 2 January 2022).

Acknowledgments: We are grateful for the logistical and technical support of Rainah Sandstrom, Nicki LeBaron, Hilary Hayford, Laura Newcomb, and Michelle Herko. A special thank you to Timothy Cox at Seattle Children's Research Institute and Ben Marwick of the University of Washington Anthropology Department for sharing their time, expertise, and resources. We would also like to thank the efforts of Liz Harper and one anonymous reviewer for their insightful comments that greatly improved the quality of this manuscript.

Conflicts of Interest: The authors declare no conflict of interest.

\section{References}

1. Gutiérrez, J.L.; Jones, C.G.; Strayer, D.L.; Iribarne, O.O. Mollusks as ecosystem engineers: The role of shell production in aquatic habitats. Oikos 2003, 101, 79-90. [CrossRef]

2. Vaughn, C.C.; Hoellein, T.J. Bivalve impacts in freshwater and marine ecosystems. Annu. Rev. Ecol. Evol. Syst. 2018, 49, 183-208. [CrossRef]

3. FAO. Fisheries and Aquaculture topics. The State of World Fisheries and Aquaculture (SOFIA). Topics Fact Sheets. Text by JeanFrancois Pulvenis. In FAO Fisheries Division; FAO: Rome, Italy, 2020.

4. Vermeij, G.J. A Natural History of Shells; Princeton University Press: Princeton, NJ, USA, 1995; Volume 15.

5. Hofmann, G.E.; Smith, J.E.; Johnson, K.S.; Send, U.; Levin, L.A.; Micheli, F.; Paytan, A.; Price, N.N.; Peterson, B.; Takeshita, Y. High-frequency dynamics of ocean $\mathrm{pH}$ : A multi-ecosystem comparison. PLoS ONE 2011, 6, e28983. [CrossRef]

6. Frieder, C.; Nam, S.; Martz, T.; Levin, L. High temporal and spatial variability of dissolved oxygen and pH in a nearshore California kelp forest. Biogeosciences 2012, 9, 3917-3930. [CrossRef] 
7. George, M.N.; Andino, J.; Huie, J.; Carrington, E. Microscale $\mathrm{pH}$ and dissolved oxygen fluctuations within mussel aggregations and their implications for mussel attachment and raft aquaculture. J. Shellfish Res. 2019, 38, 795-809. [CrossRef]

8. Lowe, A.T.; Bos, J.; Ruesink, J. Ecosystem metabolism drives $\mathrm{pH}$ variability and modulates long-term ocean acidification in the Northeast Pacific coastal ocean. Sci. Rep. 2019, 9, 963. [CrossRef]

9. Bates, N.; Best, M.; Neely, K.; Garley, R.; Dickson, A.; Johnson, R. Detecting anthropogenic carbon dioxide uptake and ocean acidification in the North Atlantic Ocean. Biogeosci. Discuss. 2012, 9, 2509-2522. [CrossRef]

10. Doney, S.C.; Fabry, V.J.; Feely, R.A.; Kleypas, J.A. Ocean Acidification: The Other $\mathrm{CO}_{2}$ Problem; Gulf Professional Publishing: Houston, TX, USA, 2009. [CrossRef]

11. Gazeau, F.; Parker, L.M.; Comeau, S.; Gattuso, J.-P.; O'Connor, W.A.; Martin, S.; Pörtner, H.-O.; Ross, P.M. Impacts of ocean acidification on marine shelled molluscs. Mar. Biol. 2013, 160, 2207-2245. [CrossRef]

12. Clements, J.C.; Chopin, T. Ocean acidification and marine aquaculture in North America: Potential impacts and mitigation strategies. Rev. Aquac. 2017, 9, 326-341. [CrossRef]

13. Halpern, B.S.; Walbridge, S.; Selkoe, K.A.; Kappel, C.V.; Micheli, F.; D’Agrosa, C.; Bruno, J.F.; Casey, K.S.; Ebert, C.; Fox, H.E. A global map of human impact on marine ecosystems. Science 2008, 319, 948-952. [CrossRef]

14. Carrington, E.; Moeser, G.M.; Dimond, J.; Mello, J.J.; Boller, M.L. Seasonal disturbance to mussel beds: Field test of a mechanistic model predicting wave dislodgment. Limnol. Oceanogr. 2009, 54, 978-986. [CrossRef]

15. Menge, B.A.; Berlow, E.L.; Blanchette, C.A.; Navarrete, S.A.; Yamada, S.B. The keystone species concept: Variation in interaction strength in a rocky intertidal habitat. Ecol. Monogr. 1994, 64, 249-286. [CrossRef]

16. Paine, R.T. Intertidal community structure. Oecologia 1974, 15, 93-120. [CrossRef]

17. Elner, R. The mechanics of predation by the shore crab, Carcinus maenas (L.), on the edible mussel, Mytilus edulis L. Oecologia 1978, 36, 333-344. [CrossRef]

18. Ebling, F.; Kitching, J.; Muntz, L.; Taylor, C.M. The ecology of Lough Ine. XIII Experimental observations of the destruction of Mytilus edulis and Nucella lapillus by crabs. J. Anim. Ecol. 1964, 33, 73-82. [CrossRef]

19. Clelland, E.S.; Saleuddin, A. Vacuolar-type ATPase in the accessory boring organ of Nucella lamellosa (Gmelin)(Mollusca: Gastropoda): Role in shell penetration. Biol. Bull. 2000, 198, 272-283. [CrossRef]

20. Norton-Griffiths, M. Some ecological aspects of the feeding behaviour of the oystercatcher Haematopus ostralegus on the edible mussel Mytilus edulis. IBIS 1967, 109, 412-424. [CrossRef]

21. Cintra-Buenrostro, C.E. Trampling, peeling and nibbling mussels: An experimental assessment of mechanical and predatory damage to shells of Mytilus trossulus (Mollusca: Mytilidae). J. Shellfish Res. 2007, 26, 221-231. [CrossRef]

22. Vermeij, G.J. Traces and trends of predation, with special reference to bivalved animals. Palaeontology 1983, 26, 455-465.

23. Vermeij, G.J. Unsuccessful predation and evolution. Am. Nat. 1982, 120, 701-720. [CrossRef]

24. Kaehler, S.; McQuaid, C. Lethal and sub-lethal effects of phototrophic endoliths attacking the shell of the intertidal mussel Perna perna. Mar. Biol. 1999, 135, 497-503. [CrossRef]

25. Christensen, A.M. Feeding biology of the sea star Astropecten irregularis Pennant. Ophelia 1970, 8, 1-134.

26. Carriker, M.R.; Zandt, D.V. Predatory behavior of a shell-boring muricid gastropod. In Behavior of Marine Animals; Springer: Berlin, Germany, 1972; pp. 157-244.

27. Palmer, A.R.; Szymanska, J.; Thomas, L. Prolonged withdrawal: A possible predator evasion behavior in Balanus glandula (Crustacea: Cirripedia). Mar. Biol. 1982, 67, 51-55. [CrossRef]

28. Xiong, X.; Cao, Y.; Li, Z.; Jiao, Y.; Du, X.; Zheng, Z. Transcriptome analysis reveals the transition and crosslinking of immune response and biomineralization in shell damage repair in pearl oyster. Aquac. Rep. 2021, 21, 100851. [CrossRef]

29. Burnett, L.E. Physiological responses to air exposure: Acid-base balance and the role of branchial water stores. Am. Zool. 1988, 28, 125-135. [CrossRef]

30. Meenakshi, V.; Blackwelder, P.L.; Wilbur, K.M. An ultrastructural study of shell regeneration in Mytilus edulis (Mollusca: Bivalvia) J. Zool. 1973, 171, 475-484. [CrossRef]

31. Sleight, V.A.; Thorne, M.A.; Peck, L.S.; Clark, M.S. Transcriptomic response to shell damage in the Antarctic clam, Laternula elliptica: Time scales and spatial localisation. Mar. Genom. 2015, 20, 45-55. [CrossRef]

32. Beedham, G. Repair of the Shell in Species of Anodonta; Zoological Society of London: London, UK, 1965; pp. 107-123.

33. Mount, A.S.; Wheeler, A.; Paradkar, R.P.; Snider, D. Hemocyte-mediated shell mineralization in the eastern oyster. Science 2004, 304, 297-300. [CrossRef]

34. Reed-Miller, C. The initial calcification process in shell-regenerating Tegula (Archaeogastropoda). Biol. Bull. 1983, 165, 265-275. [CrossRef]

35. LaBarbera, M.; Merz, R.A. Postmortem changes in strength of gastropod shells: Evolutionary implications for hermit crabs, snails, and their mutual predators. Paleobiology 1992, 18, 367-377. [CrossRef]

36. O'Neill, M.; Mala, R.; Cafiso, D.; Bignardi, C.; Taylor, D. Repair and remodelling in the shells of the limpet Patella vulgata. J. R. Soc. Interface 2018, 15, 20180299. [CrossRef] [PubMed]

37. Crane, R.; Diaz Reyes, J.; Denny, M. Bivalves rapidly repair shells damaged by fatigue and bolster strength. J. Exp. Biol. 2021, 224, jeb242681. [CrossRef] [PubMed]

38. Dunachie, J. XV-The periostracum of Mytilus edulis. Earth Environ. Sci. Trans. R. Soc. Edinb. 1963, 65, 383-411. [CrossRef] 
39. Checa, A.G.; Pina, C.M.; Osuna-Mascaró, A.J.; Rodríguez-Navarro, A.B.; Harper, E.M. Crystalline organization of the fibrous prismatic calcitic layer of the Mediterranean mussel Mytilus galloprovincialis. Eur. J. Mineral. 2014, 26, 495-505. [CrossRef]

40. Bevelander, G.; Nakahara, H. An electron microscope study of the formation of the nacreous layer in the shell of certain bivalve molluscs. Calcif. Tissue Res. 1969, 3, 84-92. [CrossRef]

41. Kadar, E.; Lobo-da-Cunha, A.; Azevedo, C. Mantle-to-shell $\mathrm{CaCO}_{3}$ transfer during shell repair at different hydrostatic pressures in the deep-sea vent mussel Bathymodiolus azoricus (Bivalvia: Mytilidae). Mar. Biol. 2009, 156, 959-967. [CrossRef]

42. Saleuddin, A.; Chan, W. Shell regeneration in Helix: Shell matrix composition and crystal formation. Can. J. Zool. 1969, 47, 1107-1111. [CrossRef]

43. Abolinš-Krogis, A. Ultrastructural study of the shell-repair membrane in the snail, Helix pomatia L. Cell Tissue Res. 1976, 172, 455-476. [CrossRef]

44. Yarra, T.; Blaxter, M.; Clark, M.S. A bivalve biomineralization toolbox. Mol. Biol. Evol. 2021, 38, 4043-4055. [CrossRef]

45. Yarra, T.; Ramesh, K.; Blaxter, M.; Hüning, A.; Melzner, F.; Clark, M.S. Transcriptomic analysis of shell repair and biomineralization in the blue mussel, Mytilus edulis. BMC Genom. 2021, 22, 7. [CrossRef]

46. Checa, A.G. Physical and biological determinants of the fabrication of molluscan shell microstructures. Front. Mar. Sci. 2018, 353. [CrossRef]

47. Hüning, A.K.; Lange, S.M.; Ramesh, K.; Jacob, D.E.; Jackson, D.J.; Panknin, U.; Gutowska, M.A.; Philipp, E.E.; Rosenstiel, P.; Lucassen, M. A shell regeneration assay to identify biomineralization candidate genes in mytilid mussels. Mar. Genom. 2016, 27, 57-67. [CrossRef] [PubMed]

48. Orr, J.C.; Fabry, V.J.; Aumont, O.; Bopp, L.; Doney, S.C.; Feely, R.A.; Gnanadesikan, A.; Gruber, N.; Ishida, A.; Joos, F. Anthropogenic ocean acidification over the twenty-first century and its impact on calcifying organisms. Nature 2005, 437, 681-686. [CrossRef]

49. Ries, J.B.; Cohen, A.L.; McCorkle, D.C. Marine calcifiers exhibit mixed responses to $\mathrm{CO}_{2}$-induced ocean acidification. Geology 2009, 37, 1131-1134. [CrossRef]

50. Zhao, X.; Han, Y.; Chen, B.; Xia, B.; Qu, K.; Liu, G. $\mathrm{CO}_{2}$-driven ocean acidification weakens mussel shell defense capacity and induces global molecular compensatory responses. Chemosphere 2020, 243, 125415. [CrossRef] [PubMed]

51. Gazeau, F.; Gattuso, J.-P.; Dawber, C.; Pronker, A.; Peene, F.; Peene, J.; Heip, C.; Middelburg, J. Effect of ocean acidification on the early life stages of the blue mussel Mytilus edulis. Biogeosciences 2010, 7, 2051. [CrossRef]

52. Kurihara, $\mathrm{H}$. Effects of $\mathrm{CO}_{2}$-driven ocean acidification on the early developmental stages of invertebrates. Mar. Ecol. Prog. Ser. 2008, 373, 275-284. [CrossRef]

53. Gazeau, F.; Alliouane, S.; Bock, C.; Bramanti, L.; López Correa, M.; Gentile, M.; Hirse, T.; Pörtner, H.-O.; Ziveri, P. Impact of ocean acidification and warming on the Mediterranean mussel (Mytilus galloprovincialis). Front. Mar. Sci. 2014, 1, 62. [CrossRef]

54. Mackenzie, C.L.; Ormondroyd, G.A.; Curling, S.F.; Ball, R.J.; Whiteley, N.M.; Malham, S.K. Ocean warming, more than acidification, reduces shell strength in a commercial shellfish species during food limitation. PLoS ONE 2014, 9, e86764. [CrossRef]

55. Vihtakari, M.; Hendriks, I.E.; Holding, J.; Renaud, P.E.; Duarte, C.M.; Havenhand, J.N. Effects of ocean acidification and warming on sperm activity and early life stages of the Mediterranean mussel (Mytilus galloprovincialis). Water 2013, 5, 1890-1915. [CrossRef]

56. Waldbusser, G.G.; Hales, B.; Langdon, C.J.; Haley, B.A.; Schrader, P.; Brunner, E.L.; Gray, M.W.; Miller, C.A.; Gimenez, I. Saturation-state sensitivity of marine bivalve larvae to ocean acidification. Nat. Clim. Chang. 2015, 5, 273-280. [CrossRef]

57. Fitzer, S.C.; Phoenix, V.R.; Cusack, M.; Kamenos, N.A. Ocean acidification impacts mussel control on biomineralisation. Sci. Rep. 2014, 4, 6218. [CrossRef] [PubMed]

58. Fitzer, S.C.; Vittert, L.; Bowman, A.; Kamenos, N.A.; Phoenix, V.R.; Cusack, M. Ocean acidification and temperature increase impact mussel shell shape and thickness: Problematic for protection? Ecol. Evol. 2015, 5, 4875-4884. [CrossRef] [PubMed]

59. Palmer, A. Relative cost of producing skeletal organic matrix versus calcification: Evidence from marine gastropods. Mar. Biol. 1983, 75, 287-292. [CrossRef]

60. Palmer, A.R. Calcification in marine molluscs: How costly is it? Proc. Natl. Acad. Sci. USA 1992, 89, 1379-1382. [CrossRef]

61. Gazeau, F.; Quiblier, C.; Jansen, J.M.; Gattuso, J.P.; Middelburg, J.J.; Heip, C.H. Impact of elevated $\mathrm{CO}_{2}$ on shellfish calcification. Geophys. Res. Lett. 2007, 34. [CrossRef]

62. Pörtner, H.O.; Langenbuch, M.; Reipschläger, A. Biological impact of elevated ocean $\mathrm{CO}_{2}$ concentrations: Lessons from animal physiology and earth history. J. Oceanogr. 2004, 60, 705-718. [CrossRef]

63. Waldbusser, G.G.; Hales, B.; Haley, B.A. Calcium carbonate saturation state: On myths and this or that stories. ICES J. Mar. Sci. 2016, 73, 563-568. [CrossRef]

64. Carrington, E. Seasonal variation in the attachment strength of blue mussels: Causes and consequences. Limnol. Oceanogr. 2002, 47, 1723-1733. [CrossRef]

65. Carrington, E. The ecomechanics of mussel attachment: From molecules to ecosystems. Integr. Comp. Biol. 2002, 42, 846-852. [CrossRef]

66. Hilbish, T.J.; Bayne, B.L.; Day, A. Genetics of physiological differentiation within the marine mussel genus Mytilus. Evolution 1994, 48, 267-286. [CrossRef]

67. Varvio, S.-L.; Koehn, R.K.; Väinölä, R. Evolutionary genetics of the Mytilus edulis complex in the North Atlantic region. Mar. Biol. 1988, 98, 51-60. [CrossRef] 
68. Saavedra, C.; Stewart, D.T.; Stanwood, R.R.; Zouros, E. Species-specific segregation of gender-associated mitochondrial DNA types in an area where two mussel species (Mytilus edulis and M. trossulus) hybridize. Genetics 1996, 143, 1359-1367. [CrossRef] [PubMed]

69. Comesaña, A.; Toro, J.; Innes, D.; Thompson, R. A molecular approach to the ecology of a mussel (Mytilus edulis-M. trossulus) hybrid zone on the east coast of Newfoundland, Canada. Mar. Biol. 1999, 133, 213-221. [CrossRef]

70. Toro, J.; Innes, D.; Thompson, R. Genetic variation among life-history stages of mussels in a Mytilus edulis-M. trossulus hybrid zone. Mar. Biol. 2004, 145, 713-725. [CrossRef]

71. Penney, R.W.; Hart, M.J.; Templeman, N.D. Shell strength and appearance in cultured blue mussels Mytilus edulis, M. trossulus, and M. edulis $\times$ M. trossulus hybrids. N. Am. J. Aquac. 2007, 69, 281-295. [CrossRef]

72. Carboni, S.; Evans, S.; Tanner, K.E.; Davie, A.; Bekaert, M.; Fitzer, S.C. Are Shell Strength Phenotypic Traits in Mussels Associated with Species Alone? Aquac. J. 2021, 1, 3-13. [CrossRef]

73. Baird, R. Measurement of condition in mussels and oysters. ICES J. Mar. Sci. 1958, 23, 249-257. [CrossRef]

74. Rueden, C.T.; Schindelin, J.; Hiner, M.C.; DeZonia, B.E.; Walter, A.E.; Arena, E.T.; Eliceiri, K.W. ImageJ2: ImageJ for the next generation of scientific image data. BMC Bioinform. 2017, 18, 529. [CrossRef]

75. Bell, E.; Gosline, J. Mechanical design of mussel byssus: Material yield enhances attachment strength. J. Exp. Biol. 1996, 199, 1005-1017. [CrossRef]

76. Palmerini, P.; Bianchi, C. Biomass measurements and weight-to-weight conversion factors: A comparison of methods applied to the mussel Mytilus galloprovincialis. Mar. Biol. 1994, 120, 273-277. [CrossRef]

77. O’Donnell, M.J.; George, M.N.; Carrington, E. Mussel byssus attachment weakened by ocean acidification. Nat. Clim. Chang. 2013, 3, 587-590. [CrossRef]

78. Martz, T.R.; Connery, J.G.; Johnson, K.S. Testing the Honeywell Durafet ${ }^{\circledR}$ for seawater pH applications. Limnol. Oceanogr. Methods 2010, 8, 172-184. [CrossRef]

79. Robbins, L.; Hansen, M.; Kleypas, J.; Meylan, S. $\mathrm{CO}_{2}$ calc-A user-friendly seawater carbon calculator for Windows, Max OS X, and iOS (iPhone). US Geol. Surv. Open-File Rep. 2010, 1280, 2010.

80. Orr, J.C.; Epitalon, J.-M.; Dickson, A.G.; Gattuso, J.-P. Routine uncertainty propagation for the marine carbon dioxide system. Mar. Chem. 2018, 207, 84-107. [CrossRef]

81. Hu, Y.; Limaye, A.; Lu, J. A new tool for 3D segmentation of computed tomography data: Drishti Paint and its applications bioRxiv 2020. [CrossRef]

82. Fernandez, E. Johnson: Johnson Transformation; R Package Version 1.4.; Johnson \& Johnson: New Brunswick, NJ, USA, 2014.

83. de Mendiburu, M. Agricolae: Statistical procedures for agricultural research. Am. J. Plant Sci. 2017, 8, 7.

84. Liao, Z.; Bao, L.-F.; Fan, M.-H.; Gao, P.; Wang, X.-X.; Qin, C.-L.; Li, X.-M. In-depth proteomic analysis of nacre, prism, and myostracum of Mytilus shell. J. Proteom. 2015, 122, 26-40. [CrossRef]

85. Marie, B.; Le Roy, N.; Zanella-Cléon, I.; Becchi, M.; Marin, F. Molecular evolution of mollusc shell proteins: Insights from proteomic analysis of the edible mussel Mytilus. J. Mol. Evol. 2011, 72, 531-546. [CrossRef]

86. Gao, P.; Liao, Z.; Wang, X.-X.; Bao, L.-F.; Fan, M.-H.; Li, X.-M.; Wu, C.-W.; Xia, S.-W. Layer-by-layer proteomic analysis of Mytilus galloprovincialis shell. PLoS ONE 2015, 10, e0133913. [CrossRef]

87. Yin, Y.; Huang, J.; Paine, M.L.; Reinhold, V.N.; Chasteen, N.D. Structural characterization of the major extrapallial fluid protein of the mollusc Mytilus edulis: Implications for function. Biochemistry 2005, 44, 10720-10731. [CrossRef] [PubMed]

88. Hattan, S.J.; Laue, T.M.; Chasteen, N.D. Purification and characterization of a novel calcium-binding protein from the extrapallial fluid of the mollusc, Mytilus edulis. J. Biol. Chem. 2001, 276, 4461-4468. [CrossRef] [PubMed]

89. Wheeler, A.; George, J.W.; Evans, C. Control of calcium carbonate nucleation and crystal growth by soluble matrx of oyster shell. Science 1981, 212, 1397-1398. [CrossRef] [PubMed]

90. Falini, G.; Albeck, S.; Weiner, S.; Addadi, L. Control of aragonite or calcite polymorphism by mollusk shell macromolecules. Science 1996, 271, 67-69. [CrossRef]

91. Marin, F.; Luquet, G.; Marie, B.; Medakovic, D. Molluscan shell proteins: Primary structure, origin, and evolution. Curr. Top. Dev. Biol. 2007, 80, 209-276.

92. Weiss, I.M.; Tuross, N.; Addadi, L.; Weiner, S. Mollusc larval shell formation: Amorphous calcium carbonate is a precursor phase for aragonite. J. Exp. Zool. 2002, 293, 478-491. [CrossRef]

93. Blundon, J.; Vermeij, G. Effect of shell repair on shell strength in the gastropod Littorina irrorata. Mar. Biol. 1983, 76, 41-45. [CrossRef]

94. Uozumi, S.; Suzuki, S. “Organic Membrane-Shell” and Initial Calcification in Shell Regeneration. J. Fac. Sci. Hokkaido Univ. Ser. IV $1979,19,37-74$.

95. Li, S.; Liu, C.; Huang, J.; Liu, Y.; Zheng, G.; Xie, L.; Zhang, R. Interactive effects of seawater acidification and elevated temperature on biomineralization and amino acid metabolism in the mussel Mytilus edulis. J. Exp. Biol. 2015, 218, 3623-3631. [CrossRef]

96. Hahn, S.; Rodolfo-Metalpa, R.; Griesshaber, E.; Schmahl, W.W.; Buhl, D.; Hall-Spencer, J.; Baggini, C.; Fehr, K.; Immenhauser, A. Marine bivalve shell geochemistry and ultrastructure from modern low pH environments: Environmental effect versus experimental bias. Biogeosciences 2012, 9, 1897-1914. [CrossRef]

97. Gaylord, B.; Hill, T.M.; Sanford, E.; Lenz, E.A.; Jacobs, L.A.; Sato, K.N.; Russell, A.D.; Hettinger, A. Functional impacts of ocean acidification in an ecologically critical foundation species. J. Exp. Biol. 2011, 214, 2586-2594. [CrossRef] [PubMed] 
98. Melzner, F.; Stange, P.; Trübenbach, K.; Thomsen, J.; Casties, I.; Panknin, U.; Gorb, S.N.; Gutowska, M.A. Food supply and seawater $\mathrm{pCO}_{2}$ impact calcification and internal shell dissolution in the blue mussel Mytilus edulis. PLoS ONE 2011, 6, e24223. [CrossRef] [PubMed]

99. Wolowicz, M.; Goulletquer, P. The shell organic content in the energy budget of Mytilus trossulus from the South Baltic. Haliotis 1999, 28, 1-10.

100. Melzner, F.; Thomsen, J.; Koeve, W.; Oschlies, A.; Gutowska, M.A.; Bange, H.W.; Hansen, H.P.; Körtzinger, A. Future ocean acidification will be amplified by hypoxia in coastal habitats. Mar. Biol. 2013, 160, 1875-1888. [CrossRef]

101. Thomsen, J.; Casties, I.; Pansch, C.; Körtzinger, A.; Melzner, F. Food availability outweighs ocean acidification effects in juvenile Mytilus edulis: Laboratory and field experiments. Glob. Chang. Biol. 2013, 19, 1017-1027. [CrossRef]

102. Hüning, A.K.; Melzner, F.; Thomsen, J.; Gutowska, M.A.; Krämer, L.; Frickenhaus, S.; Rosenstiel, P.; Pörtner, H.-O.; Philipp, E.E.; Lucassen, M. Impacts of seawater acidification on mantle gene expression patterns of the Baltic Sea blue mussel: Implications for shell formation and energy metabolism. Mar. Biol. 2013, 160, 1845-1861. [CrossRef]

103. Roberts, E.A.; Newcomb, L.A.; McCartha, M.M.; Harrington, K.J.; LaFramboise, S.A.; Carrington, E.; Sebens, K.P. Resource allocation to a structural biomaterial: Induced production of byssal threads decreases growth of a marine mussel. Funct. Ecol. 2021, 35, 1222-1239. [CrossRef]

104. Paine, R.T. Size-limited predation: An observational and experimental approach with the Mytilus-Pisaster interaction. Ecology 1976, 57, 858-873. [CrossRef] 